\title{
Impacts of Changes in Climate, Land Use and Land Cover on Atmospheric Mercury
}

H. Zhang ${ }^{\mathrm{a}}$, C. D. Holmes ${ }^{\mathrm{b}}$ and S. Wu $\mathrm{u}^{\mathrm{a}, \mathrm{c}}$

3

${ }^{a}$ Department of Geological and Mining Engineering and Sciences, Michigan Technological

4 University, Houghton, Michigan, USA, 49931

$5{ }^{b}$ Department of Earth, Ocean and Atmospheric Science, Florida State University, Tallahassee,

6 Florida, USA, 32306

$7{ }^{\mathrm{c}}$ Atmospheric Sciences Program and Department of Civil and Environmental Engineering,

8 Michigan Technological University, Houghton, Michigan, USA, 49931

9 Correspondence to: S. Wu (ㄴwu@mtu.edu)

10 Key words: climate change, land use/land cover change, atmospheric mercury, mercury 11 deposition

\section{Abstract}

13 Mercury is an important pollutant that can be transported globally due to its long lifetime in the atmosphere. Atmosphere-surface exchange is a major process affecting the cycling of mercury in the global environment and its impacts on food webs. We investigate the sensitivities of the airsurface exchange, atmospheric transport, and budget of mercury to projected 2000-2050 changes in climate and land use/land cover with a global chemical transport model (GEOS-Chem). We find that annual mean $\operatorname{Hg}(0)$ dry deposition flux over land could increase by up to $20 \%$ in northern mid-latitudes by 2050 due to increased vegetation and foliage density. Climate change can significantly affect both the wet deposition and atmospheric chemistry of mercury. In response to the projected climate change, the annual mean wet deposition flux increases over most continental regions and decreases over most of the mid-latitude and tropical oceans. The annual mean mercury wet deposition flux over northern and southern high latitudes increases by

$247 \%$ and $8 \%$ respectively, largely driven by increase in precipitation there. Surface $\mathrm{Hg}(0)$ is 25 predicted to increase generally, because high temperatures decrease $\mathrm{Hg}(0)$ oxidation by bromine 
and high moisture increases aqueous $\mathrm{Hg}(\mathrm{II})$ photo reduction. The combined effects of projected

27 changes in climate, land use, and land cover increase mercury deposition to the continental biosphere and decrease mercury deposition to the marine biosphere.

\section{Introduction}

Mercury is a toxic and bioaccumulative pollutant in the environment and has important implications for public health, wildlife, and ecosystems (Choi and Grandjean, 2008; Lindberg et al., 2007; Mergler et al., 2007; Scheulhammer et al., 2007; UNEP, 2013). The long atmospheric lifetime of elemental mercury (around one year) enables it to be transported long distances before depositing to the Earth surfaces, making it a global pollutant (Lindqvist and Rodhe, 1985; Schroeder and Munthe, 1998). Due to its volatility, some of the depoited mercury can be reemited back into the atmosphere (Selin et al., 2008; Xu et al., 1999).

37 The atmosphere-surface exchange and budget of atmospheic mercury are affected by global changes in anthropogenic emissions, climate and land use/land cover. Most previous studies of global change have focused on the effects of anthropogenic emissions and their implications for policy. For example, Corbitt et al. (2011) studied the source-receptor relationship for mercury deposition with the present-day and 2050s anthropogenic emissions. Amos et al. (2013) first investigated the impacts of legacy mercury emissions on the present-day mercury cycle and then projected the effects from future changes in anthropogenic mercury emissions. Selin (2014) identified the challenges for implementing Minamata Convention to regulate anthropogenic mercury emission and evaluating its influences on global biogeochemical cycling of mercury. Few studies have addressed the effects of changing climate or land use/land cover on atmospheric mercury. Lei et al. (2014) found that the benefits from reductions in domestic United States mercury emissions for the 2000-2050 period would be largely offset by rising anthropogenic emissions overseas and rising natural emissions. Megaritis et al. (2014) investigated the effects of climate change on atmospheric mercury concentration and deposition over the eastern United States and concluded that rising future temperatures would increase elemental mercury oxidation and increase divalent mercury concentrations. Hansen et al. (2015) studied the impacts of climate change on atmospheric mercury deposition in the Arctic following the Special Report on Emissions Scenarios (SRES-A1B) (Nakicenovic et al., 2000) as a 
sensitivity study and found that climate change will reduce atmospheric mercury deposition to 56 the Arctic.

57 Climate change has the potential to influence atmospheric mercury through multiple pathways. The changes in precipitation directly affect the spatiotemporal patterns of mercury wet deposition. Past studies have shown that the variability in precipitation plays a critical role in affecting the present-day mercury wet deposition (Gratz et al., 2009; Holmes et al., 2016; Nair et al., 2013; Prestbo and Gay, 2009; Risch et al., 2012b). The observed significant interannual variability in present-day atmospheric mercury deposition (Blackwell et al., 2014) also indicates that meteorology is a key factor affecting the atmospheric abundance, distribution and atmosphere-surface exchange of mercury.

Changes in temperature could alter the atmospheric mercury chemistry leading to changes in mercury speciation (i.e. elemental vs. divalent mercury; gas vs. particle phase) and consequently deposition since different mercury species have different solubility and other deposition properties. The changes in future climate could also affect the atmosphere-surface exchange of elemental mercury. Previous studies have shown that evasion of mercury from surface soil could be affected by solar radiation (Eckley and Branfireun, 2008; Ericksen et al., 2006; Fu et al., 2012b; Gustin et al., 2006; Obrist et al., 2006) and air temperature (Almeida et al., 2009; Obrist et al., 2006; Poissant et al., 1999). Emission of mercury from surface ocean can also be affected by environmental factors such as temperature, solar radiation and surface winds (Andersson et al., 2008; Nightingale et al., 2000; Poissant et al., 2000; Soerensen et al., 2010; Soerensen et al., 75 2013; Soerensen et al., 2014).

Significant changes in land use/land cover are expected in the coming decades in response to changes in climate, atmospheric $\mathrm{CO}_{2}$ concentration, as well as anthropogenic activities such as agriculture expansion, deforestation, and reforestation (Bachelet et al., 2001; Cox et al., 2004; Cramer et al., 2001; Houghton et al., 2000; Turner et al., 1994). Previous work has investigated the influence of land use/land cover change on atmospheric chemical composition such as ozone

81 (Ganzeveld et al., 2010; Wu et al., 2012), but the potential impacts on atmospheric mercury from 82 changes in land use/land cover have not been examined yet. Recent assessments have suggested 83 vegetation to be a net sink of atmospheric mercury (Ericksen and Gustin, 2004; Gustin et al., 84 2008; Hanson et al., 1995; Hartman et al., 2009; Wang et al., 2014). Strong positive correlations 
between mercury deposition flux and leaf area have been indicated by studies of Gao and Wesely (1995) and Zhang et al. (2009). Zhang et al. (2009) showed that $\mathrm{Hg}(0)$ dry deposition velocity onto forests tended to be 2-5 times higher than other vegetated surfaces. We present here the first study on the impacts of global climate change and land use/land cover change (driven by climate change, increasing atmospheric $\mathrm{CO}_{2}$ concentration and agricultural land use change) on atmospheric mercury.

\section{Model Description and Approach}

\subsection{Model Description}

We use the GEOS-Chem model version v9-02 (www.geos-chem.org) with coupled atmosphereland-ocean mercury simulation (Holmes et al., 2010; Selin et al., 2008; Soerensen et al., 2010). The model simulates three forms of mercury in the atmosphere: gaseous elemental $\operatorname{Hg}(0)$, gaseous oxidized $\mathrm{Hg}(\mathrm{II})$ and particle-bound $\mathrm{Hg}(\mathrm{II}) . \mathrm{Hg}(\mathrm{II})$ is assumed to be in equilibrium between gas and particle phases at all times and the fractions in gas and particle phases depend on temperature and aerosol loadings (Amos et al., 2012; Rutter and Schauer, 2007a, b). Atmospheric $\mathrm{Hg}(0)$ is oxidized by bromine (Br) to form $\mathrm{Hg}(\mathrm{II})$ products and in-cloud reduction of $\mathrm{Hg}$ (II) is also included in order to match observed surface mercury concentrations (Holmes et al., 2010). The oxidation of $\operatorname{Hg}(0)$ involves a two-step reaction: (1) atmospheric $\operatorname{Hg}(0)$ reacts with $\mathrm{Br}$ to form unstable $\mathrm{HgBr}$; (2) $\mathrm{HgBr}$ can either dissociate or react with $\mathrm{Br}$ or hydroxyl radical $(\mathrm{OH})$ to form final product $(\mathrm{Hg}(\mathrm{II})$ ) (Holmes et al., 2010). Tropospheric Br fields for the present-day are archived from a GEOS-Chem full chemistry simulation (Parrella et al., 2012) and remain unchanged in our future climate and land use/cover simulations. Gaseous and particle-bound $\mathrm{Hg}(\mathrm{II})$ are subject to wet deposition, which includes scavenging in convective updrafts and rainout and washout from large-scale precipitation as described in Liu et al. (2001) with updates by Wang et al. (2011) and Amos et al. (2012). Sea salt uptake of gaseous phase $\mathrm{Hg}(\mathrm{II})$ in the marine boundary layer (MBL) is accounted for following Holmes et al. (2010).

$\mathrm{Hg}(0)$ is emitted from both natural and anthropogenic sources while $\mathrm{Hg}(\mathrm{II})$ only has anthropogenic sources. Anthropogenic emissions are specified from the GEIA (Global Emission Inventories Activity) 2005 inventory (Pacyna et al., 2010) as implemented by Corbitt et al. (2011) and Streets et al. (2009). Anthropogenic emissions over the United States and Canada are replaced by regional inventories prepared by Zhang et al. (2012b). Anthropogenic mercury 
115

emissions are held constant in our future modeling scenarios in order to focus on the effects of climate and land use/land cover on natural emissions and atmospheric chemistry.

The atmosphere-terrestrial exchange of $\operatorname{Hg}(0)$ is bi-directional, but only some recent model developments have coupled the deposition (downward flux) and emission (upward flux) together to estimate the net atmosphere-surface flux based on the gradient between an ambient mercury concentration and a "compensation point" inferred from the surface characteristics (Bash et al., 2007; Bash, 2010; Wang et al., 2014). Such treatments have not been implemented into global chemical transport models yet due to the limited filed or lab data to validate the complicated parameterization processes in the coupled model (Wang et al., 2014). The GEOS-Chem model used in this study treats deposition and emission of $\operatorname{Hg}(0)$ separately. More details about the dry deposition process will be discussed in Sec 2.2.

A fraction of $\mathrm{Hg}$ (II) deposited to terrestrial reservoir can be quickly converted to $\operatorname{Hg}(0)$ and reemitted back to the atmosphere, which is called "prompt recycling" (Selin et al., 2008). For the version of GEOS-Chem model used in this study, it is assumed that $20 \%$ of total $\mathrm{Hg}$ (II) deposited to land surface will be immediately released to the atmosphere as $\operatorname{Hg}(0)$ when there is no snow cover (Selin et al., 2008). For snow covered land surfaces, a snow pack reservoir accounts for the conversion of deposited $\operatorname{Hg}($ II) to $\operatorname{Hg}(0)$ under sunlit conditions (Holmes et al., 2010). The reservoir lifetime is 180 days but decreases to 21 days when temperature exceeds 270K (Fain et al., 2007; Fain et al., 2008).

Dry deposition of $\operatorname{Hg}(0)$ to the ocean surface in GEOS-Chem model is simulated as part of the bi-directional exchange process in the surface slab ocean model of Soerensen et al. (2010). In this model, three species of mercury in the surface ocean mixed layer are simulated: $\operatorname{Hg}(0)$, $\mathrm{Hg}(\mathrm{II})$ and nonreactive nonvolatile mercury. Atmospheric deposition of mercury contributes significantly to the surface ocean mixed layer, but the deep ocean also accounts for considerable amount of mercury inputs to surface ocean mixed layer. Vertical exchange between the surface ocean and the deep ocean are retained through entrainment/detrainment and Ekman pumping (Soerensen et al., 2010). In the surface ocean mixed layer, biological primary productivity and solar radiation both favor $\mathrm{Hg}(\mathrm{II})$ reduction to $\mathrm{Hg}(0)$. Net emission of $\mathrm{Hg}(0)$ from ocean surface is a function of the available $\operatorname{Hg}(0)$ pool in the surface ocean, sea surface temperature and surface wind speed. Net emission of $\operatorname{Hg}(0)$ from surface ocean is estimated to be about $2310 \mathrm{Mg}$ for 
145

present-day in the present work, which is consistent with most other estimates of $2000-3000 \mathrm{Mg}$ $\mathrm{yr}^{-1}$ (Bergan et al., 1999; Holmes et al., 2010; Lindberg et al., 2007; Mason and Sheu, 2002; Seigneur et al., 2004; Selin et al., 2007; Shia et al., 1999; Soerensen et al., 2010).

\subsection{Simulation Design}

All the model simulations are driven by meteorology fields archived from the NASA Goddard Institute for Space Studies (GISS) general circulation model (GCM 3) (Rind et al., 2007). The GISS GCM 3 has a horizontal resolution of $4^{\circ}$ latitude by $5^{\circ}$ longitude with 23 vertical layers extending from the surface to $0.002 \mathrm{hPa}$ (about $85 \mathrm{~km}$ altitude). The meteorological data is archived with 6-hour time resolution (3-hours for surface variables and mixing depth). The interface between the GISS GCM 3 and GEOS-Chem is described in Wu et al. (2007). The simulation of 2000-2050 climate change with the GISS model follows the IPCC A1B scenario (IPCC, 2001). We carry out 5-year Hg simulations with the GEOS-Chem model for the 2000s (1998-2002) and 2050s (2048-2052) climate. Unless noted otherwise, our analyses on the perturbations to atmospheric mercury due to climate change are based on 5-yr average model results.

We follow Wu et al. (2012) to conduct GEOS-Chem sensitivity simulations to separately identify the effects of climate change, natural vegetation change (referred to land cover change here) induced by climate change and increasing atmospheric $\mathrm{CO}_{2}$ fertilization, and anthropogenic land use change such as agricultural expansion (referred to land use change here). The 2000-2050 changes in natural vegetation are calculated with the Lund-Potsdam-Jena Dynamic Global Vegetation Model (LPJ DGVM) (Sitch et al., 2003) driven by the same meteorology from the GISS GCM 3 and atmospheric $\mathrm{CO}_{2}$ concentrations following the IPCC A1B scenario (IPCC, 2001). Changes in anthropogenic land use over the period of 2000-2050 were simulated by the IMAGE model following the IPCC A1B scenario (IMAGE-Team, 2001; IPCC, 2001; MNP, 2006).

The LPJ DGVM simulates vegetation cover, density and other variables for nine different plant functional types (PFTs) (Sitch et al., 2003; Wu et al., 2012). Vegetation data including vegetation density (expressed as leaf area index, or LAI) and fractional coverage from LPJ are archived at $1^{\circ} \times 1^{\circ}$ (longitude $\mathrm{x}$ latitude) resolution. We use 10-yr average vegetation data to 
175

176

177

178

179

180

181

182

183

184

185

186

187

188

189

190

191

192

193

194

195

196

197

198

199

200

201

202

203

204

derive the 2000-2050 changes in land use/land cover (1990-2000 for the present-day and 20402050 for the future). Dry deposition of $\mathrm{Hg}(0)$ and gas phase $\mathrm{Hg}(\mathrm{II})$ follows a standard resistancein-series scheme (Wang et al., 1998; Wesely, 1989) with updates to include the impacts of Leaf Area Index (LAI) on stomatal resistance (Gao and Wesely, 1995). Dry deposition velocities for each grid box are calculated with surface values of momentum and sensible heat flux, temperatures, solar radiation and other meteorology variables (Bey et al., 2001).

We conduct five model simulations to separate the impacts associated with climate change and those associated with land use/land cover change: (1) present-day climate and present-day land use and land cover (2000 climate +2000 LU\&LC), (2) future climate and present-day land use and land cover (2050 climate +2000 LU\&LC), (3) present-day climate and future land use and land cover (2000 climate +2050 LU\&LC), (4) present-day climate and present-day land cover (with only natural vegetation) (2000 climate +2000 LC), (5) present-day climate and future land cover (with only natural vegetation) (2000 climate +2050 LC). In simulations (4) and (5), only natural vegetation are included while anthropogenic land use such as crops are excluded. Anthropogenic, biomass burning and geogenic emissions of mercury remain at the present-day levels for all the cases, while ocean and land emissions respond dynamically to changes in climate and land use/land cover. The climate-induced changes in temperature, precipitation, cloudiness, and atmospheric transport can all affect atmospheric mercury. In this study, we do not account for the potential impacts from climate change on net primary productivity and the wind-driven Ekman pumping. Case (1) serves as the control run and the difference between case (2) and case (1) reflects the influence from climate change. The difference between (4) and (5) represents the impacts from land cover change while the difference between (3) and (1) are the impacts from the combined effects from land use and land cover. Following (Selin et al., 2008), steady state of emissions and deposition on the $4^{\circ} \times 5^{\circ}$ model grid is applied to compute natural soil mercury concentrations in the preindustrial conditions. For the present-day, soil mercury concentrations are increased by 15\% globally (Mason and Sheu, 2002) and distributed following the pattern of present-day anthropogenic deposition. For present-day, each simulation covers a five-year period (i.e. 1998-2002 or 2048-2052) which is preceded by 5 years of spin-up. All the results analyzed and discussed in this study are based on 5-year averages. 


\subsection{Model Evaluation}

207 Mercury simulations with the GEOS-Chem model driven by the NASA/GEOS assimilated 208 meteorological fields have been extensively evaluated in previous studies (Amos et al., 2012; 209 Holmes et al., 2010; Selin et al., 2007; Soerensen et al., 2010; Song et al., 2015; Strode et al., 210 2007; Zhang et al., 2012b). In this study, we first evaluate the GEOS-Chem mercury simulations 211 driven by GISS GCM 3 meteorological fields. Fig. 1 shows the simulated concentrations of total 212 gaseous mercury ( $\mathrm{TGM}=\mathrm{Hg}(0)+$ gas phase $\mathrm{Hg}(\mathrm{II}))$ in surface air compared with observations.

213 In general, the model reproduces the spatial distribution of atmospheric mercury at 39 214 continental sites $\left(r^{2}=0.78\right)$ although it tends to underestimate the TGM surface concentrations. 215 The model calculated mean and standard deviation (SD) for atmospheric mercury concentrations 216 over these sites is $1.52 \pm 0.25 \mathrm{ng} / \mathrm{m}^{3}$, compared to the $1.86 \pm 0.99 \mathrm{ng} / \mathrm{m}^{3}$ for the observational 217 data. One likely reason for the underestimate of the surface TGM concentration in our model is 218 the relatively coarse vertical resolution in the boundary layer $(0.4 \mathrm{~km})$, which is unable to resolve 219 vertical TGM gradients in strong emission regions, where many TGM measurements are made. 


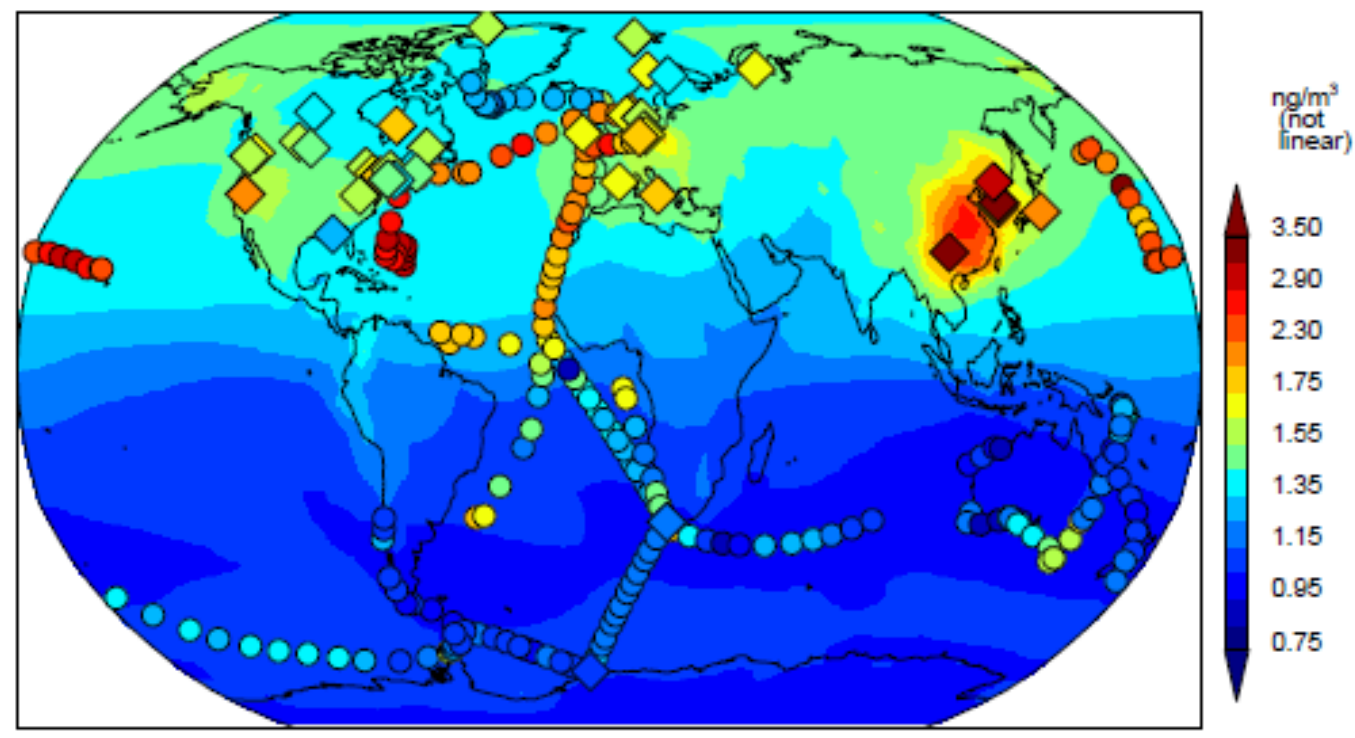

221 Figure 1. Global distribution of TGM concentrations in surface air. Model results (background) 222 are annual average for year 1998-2002. Measurements data (diamonds) and all other observed 223 ship cruise data (circles) are as those used from (Holmes et al., 2010).

224 Fig. 2 shows the model calculated annual average wet deposition flux for the present-day (1998225 2002) compared with measurements from the Mercury Deposition Network (MDN) (NADP, 226 2009) over North America. The model simulates the magnitude of wet deposition flux 227 reasonably well with a mean bias of $-5 \%$ relative to the MDN observation data with correlation 228 of $\mathrm{r}^{2}=0.26$. The model overestimates the wet deposition flux in the southwest United States. This 229 could be partly driven by the overestimated precipitation by the GISS CCM 3. For example, we 230 find that at one site in New Mexico (NM10), the precipitation from GISS GCM 3 is 2.4 times 231 higher than the observed precipitation from MDN while the model simulated wet deposition at 232 that site is $83 \%$ higher than the measurement data from MDN. The modelled largest mercury wet 233 deposition flux is found in Southeast United States as in other studies (Holmes et al., 2010; Selin 234 and Jacob, 2008; Zhang et al., 2012b; Zhang and Jaegle, 2013) but the model did not capture the 235 magnitude of the observed wet deposition flux with a mean bias of $-30 \%$ relative to the measured 

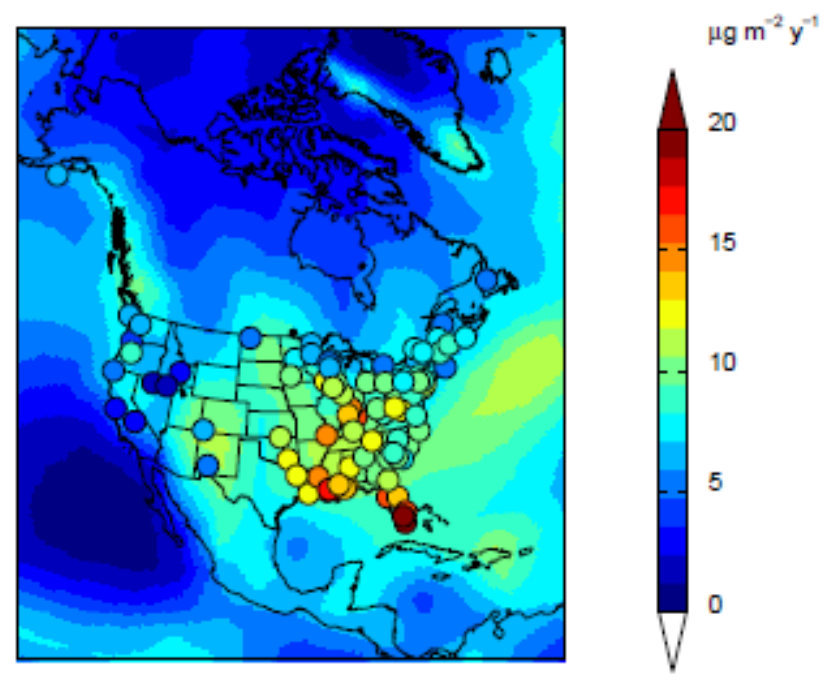

239 Figure 2. Annual average total mercury (gas phase $\mathrm{Hg}(\mathrm{II})+$ particulate phase $\mathrm{Hg}(\mathrm{II})$ ) wet 240 deposition flux (in $\mu \mathrm{g} / \mathrm{m} 2 / \mathrm{yr}$ ) over North America. Model results (background) for 1998-2002 241 annual average are compared to observed data from the Mercury Deposition Network (circles) 242 from 2006-2008 as used in (Holmes et al., 2010). More details about the data can be found in 243 (Holmes et al., 2010).

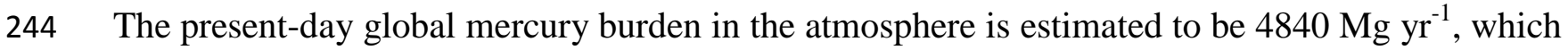
245 is in the range of $4600-5600 \mathrm{Mg} \mathrm{yr}^{-1}$ as estimated by literature studies (Amos et al., 2012; 246 Selin, 2009; Shia et al., 1999). Mercury emission from geogenic sources follows Selin et al. 247 (2007) with a global total of $500 \mathrm{Mg} \mathrm{yr}^{-1}$ and is assumed to remain constant in the future. 248 Biomass burning emission of mercury is estimated to be $243 \mathrm{Mg} \mathrm{yr}^{-1}$ following the distribution of 249 Global Fire Emissions Database version 3 (van der Werf et al., 2010) of CO with a constant $250 \mathrm{Hg} / \mathrm{CO}$ ratio of $100 \mathrm{nmol} \mathrm{mol}^{-1}$ (Holmes et al., 2010). The mercury emission from soil is affected 251 by solar radiation following Holmes et al. (2010) and Zhang et al. (2001) with the global total 252 emission calculated to be $814 \mathrm{Mg} \mathrm{yr}^{-1}$ for the present-day. 
253 We calculate $241 \mathrm{Mg} \mathrm{yr}^{-1}$ and $204 \mathrm{Mg} \mathrm{yr}^{-1}$ re-emission of $\mathrm{Hg}(0)$ from the non-snow covered and snow covered land surface respectively. We define net emission of $\operatorname{Hg}(0)$ from the terrestrial surfaces as total $\operatorname{Hg}(0)$ emissions from terrestrial surface minus total $\operatorname{Hg}(0)$ dry deposition to terrestrial surface, i.e. (soil emission + biomass burning emission + geogenic emission + prompt recycling emission - dry deposition). We then calculate the net emission of $\operatorname{Hg}(0)$ from terrestrial surface for present-day is $500 \mathrm{Mg} \mathrm{yr}^{-1}$, lower than the previous bottom-up estimates 1140-5280 Mg yr ${ }^{-1}$ of Mason (2009) and Pirrone et al. (2010). It is lower than the average of $1070 \mathrm{Mg} \mathrm{yr}^{-1}$ (uncertainty range: -510 to $3130 \mathrm{Mg} \mathrm{yr}^{-1}$ ) of Song et al. (2015) from a standard GEOS-Chem simulation and the major uncertainty there comes from estimation of soil emission $\left(1680 \pm 840 \mathrm{Mg} \mathrm{yr}^{-1}\right)$; while it is close to the average of $340 \mathrm{Mg} \mathrm{yr}^{-1}$ (uncertainty range: -590 to

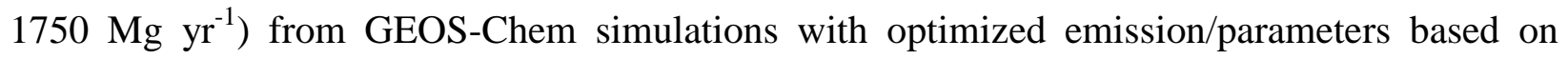
Bayesian inversion of Song et al. (2015). Recent work of Agnan et al. (2016) estimated a global net emission of $\operatorname{Hg}(0)$ from terrestrial surface to have a median of $607 \mathrm{Mg} \mathrm{yr}^{-1}$ with uncertainty range of $\left[-513 \mathrm{Mg} \mathrm{yr}^{-1}, 1653 \mathrm{Mg} \mathrm{yr}^{-1}\right.$ ] (representing 37.5th and 62.5th percentile range) by extrapolating the best statistical distribution of measurement fluxes from different land cover types and surfaces.

Previous studies (Zhang et al., 2009; Zhang et al., 2012a) have shown that $\operatorname{Hg}(0)$ dry deposition velocity values are larger over ecosystem with larger LAI due to the dominant effect of LAI and gaseous $\mathrm{Hg}(\mathrm{II})$ has much larger dry deposition velocity than that of $\mathrm{Hg}(0)$. Here, the calculated $\mathrm{Hg}(0)$ dry deposition velocity ranges from $0.01 \mathrm{~cm} / \mathrm{s}$ to $0.05 \mathrm{~cm} / \mathrm{s}$ globally with higher values $(0.03-0.05 \mathrm{~cm} / \mathrm{s})$ over vegetated areas such as Southeast United States, Amazon forest and northern mid-latitudes. Gaseous $\mathrm{Hg}$ (II) dry deposition velocity is estimated to range from 0.06 $5 \mathrm{~cm} / \mathrm{s}$ globally in this work. These calculated values are well within the range reported by previous studies (Zhang et al., 2009; Zhang et al., 2012a). Annual mean $\mathrm{Hg}(0)$ dry deposition flux in the central and eastern United States from this work ranging from $11-20 \mu \mathrm{g} / \mathrm{m}^{2} / \mathrm{yr}$ are in the range of Zhang et al. (2012a) which estimated $\mathrm{Hg}(0)$ dry deposition flux to be $5.2-34.4$ $\mu \mathrm{g} / \mathrm{m}^{2} / \mathrm{yr}$ at sites in this region, obtaining good agreements with litterfall measurements (Risch et al., 2012a). The global total $\mathrm{Hg}(0)$ dry deposition to the land of $1440 \mathrm{Mg}$ for present-day is well within the previous published data (Holmes et al., 2010; Selin et al., 2008; Song et al., 2015). These imply that the model estimates could be reasonable for $\mathrm{Hg}(0)$ dry deposition. 


\subsection{Effects on Atmospheric Chemistry and Composition}

284 Bromine reactions with $\operatorname{Hg}(0)$ are very sensitive to air temperature, with the net oxidation rate

285

286

287

288

289

290

291

292

293

294

295

296

297

298

299

300

301

302 falling roughly $11 \%$ for each $1 \mathrm{~K}$ increase in temperature (Holmes et al., 2006). Fig. 3 shows the zonal mean gross oxidation of $\mathrm{Hg}(0)$ for present-day and the difference due to 2000-2050 climate change. Bromine concentrations are assumed to be the same in the future climate since little is known about how its marine sources may change (Hossaini et al., 2013; Hughes et al., 2012). The higher tropospheric temperatures in the future climate favor decomposition of the $\mathrm{HgBr}$ reaction intermediate and therefore suppress oxidation of $\mathrm{Hg}(0)$ to $\mathrm{Hg}(\mathrm{II})$ (Fig. 3). Although the mechanism for atmospheric reduction of $\mathrm{Hg}(\mathrm{II})$ is uncertain, numerous studies have suggested that aqueous photochemical reactions in clouds or aerosols are involved (Lin et al., 2006; Subir et al., 2011, 2012). Rising atmospheric temperatures in the future climate expand the regions where liquid-water clouds exist to higher latitudes and altitudes. Our model therefore predicts $5 \%$ greater $\mathrm{Hg}(\mathrm{II})$ reduction in the future climate. The interannual variability (IAV, calculated as standard deviation of annual mean values) in present-day $\mathrm{Hg}(\mathrm{II})$ reduction is $16 \mathrm{Mg} \mathrm{yr}^{-1}$, which is $0.9 \%$ of the mean. In the future scenario, the IAV rises to $27 \mathrm{Mg} \mathrm{yr}^{-1}$, which is $1.4 \%$ of the future mean. Against this low IAV, the simulated 5\% increase in $\mathrm{Hg}$ (II) reduction is significant. Despite the uncertainties associated with the current atmospheric mercury redox chemistry (Holmes et al., 2006; Holmes et al., 2010; Lin et al., 2006; Pongprueksa et al., 2008; Subir et al., 2011, 2012), our results suggest that climate change could lead to large perturbations to atmospheric mercury chemistry. 

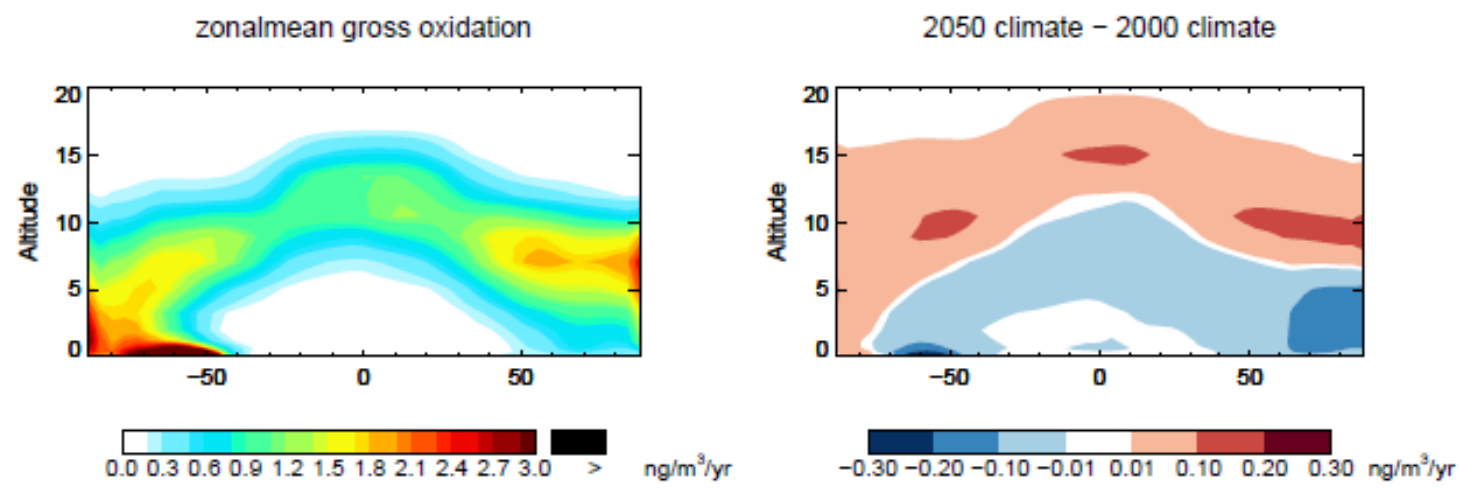

304 Figure 3. Zonal mean gross oxidation of $\mathrm{Hg}(0)$ (left) and the difference due to 2000-2050 climate 305 change (right).

306 The change in future temperature could have potential effects on the partitioning of $\mathrm{Hg}$ (II) 307 between gas and particulate phase. Amos et al. (2012) has shown that implementing the 308 partitioning of $\mathrm{Hg}$ (II) between gas and particulate phase in GEOS-Chem model has resulted in $309 \mathrm{Hg}(\mathrm{II})$ fraction in the particulate phase from less than $10 \%$ in warm air with low aerosol and 310 more than $90 \%$ in cold air with high aerosol load. This feature is reflected in our model results 311 for the present-day conditions as shown in Fig. 4. The increase in global surface temperature by 312 about $2 \mathrm{~K}$ in the future favors more $\mathrm{Hg}(\mathrm{II})$ in the gas phase over the particulate phase in most 313 parts of the world (Fig. 4) with the mean fraction of $\mathrm{Hg}$ (II) partitioned into the particle phase 314 decreasing by 5\% globally in both January and July. This would have important influences for 315 mercury speciation and subsequent effects on global distribution of mercury deposition. 316 Particulate $\mathrm{Hg}$ (II) can be more efficiently scavenged by snow than gaseous $\mathrm{Hg}$ (II) (Amos et al., 317 2012; Holmes et al., 2010; Selin et al., 2008). One important implication could be the influence 318 on mercury deposition in the high latitudes as suggested by Amos et al. (2012) which showed 319 that the implementation of the partitioning relationship leads to increasing $\mathrm{Hg}$ (II) deposition at 320 high latitudes comparing to a sensitivity simulation that assumes all $\mathrm{Hg}$ (II) to be all in gaseous 321 phase. The model results predict that future climate could cause the fraction of $\mathrm{Hg}(\mathrm{II})$ in 322 particulate phase to decrease by $45 \%$ and 5\% in January in northern (Arctic Ocean) and southern 323 (Antarctic Ocean) high latitude (poleward of $70^{\circ} \mathrm{N}$ and $65^{\circ} \mathrm{S}$ ) while no significant change is 
found in July in both high latitudes, mainly driven by the increase in surface air temperature in

325 these two regions in January. We find here that particle phase $\mathrm{Hg}$ (II) concentration decreases in 326 high latitudes in both hemispheres affected by the gas phase portioning and also the increase in 327 precipitation over high latitudes.
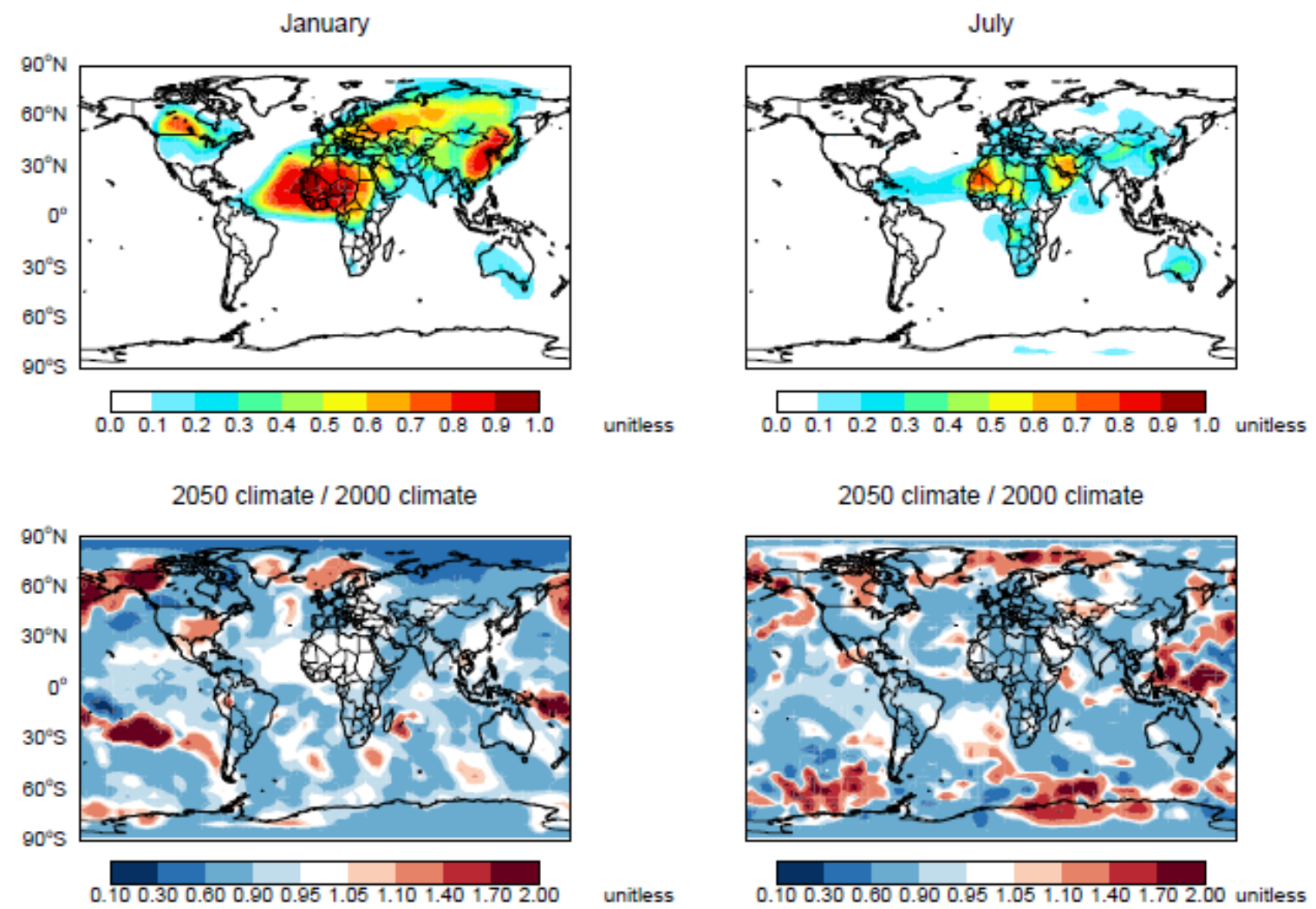

Figure 4. Top panels are the mean fraction of $\mathrm{Hg}$ (II) partitioned into the particle phase in surface air in January (top left) and July (top right). Bottoms are the respective ratio due to 2000-2050 climate change.

332 We find that climate change leads to general increase in future surface $\mathrm{Hg}(0)$ concentration by up to $5 \%$ and $7 \%$ in northern and southern hemisphere respectively mainly as a combined result of 334 suppressed $\mathrm{Hg}(0)$ oxidation in the troposphere and increased in-cloud reduction of $\mathrm{Hg}(\mathrm{II})$ (Fig. 5). The largest increase by up to $0.14 \mathrm{ng} / \mathrm{m}^{3}$ occurs in eastern China where the present-day surface $\operatorname{Hg}(0)$ concentration in urban sites are often several folds higher than that of those in

337 North America and Europe (Fu et al., 2012a). We further divide the continental regions into 338 North America $\left(130-80^{\circ} \mathrm{W}\right.$ and $\left.10-70^{\circ} \mathrm{N}\right)$, Europe $\left(10^{\circ} \mathrm{W}-50^{\circ} \mathrm{E}\right.$ and $\left.35-70^{\circ} \mathrm{N}\right)$, Asia $\left(63-145^{\circ} \mathrm{E}\right.$ 339 and $\left.10-58^{\circ} \mathrm{N}\right)$, Africa $\left(15^{\circ} \mathrm{W}-50^{\circ} \mathrm{E}\right.$ and $\left.35^{\circ} \mathrm{S}-35^{\circ} \mathrm{N}\right)$, South America $\left(80-40^{\circ} \mathrm{W}\right.$ and $\left.55^{\circ} \mathrm{S}-10^{\circ} \mathrm{N}\right)$ 
and Australia $\left(115-150^{\circ} \mathrm{E}\right.$ and $\left.35-15^{\circ} \mathrm{S}\right)$ shown as the red boxes in the bottom right of Fig. 5 . We find climate change causes annual average surface $\operatorname{Hg}(0)$ concentration to increase by $4 \%, 4 \%$, $3 \%, 5 \%, 5 \%$ and $7 \%$ increase in these respective regions and these changes are statistically significant at the 95\% confidence level. Unless noted otherwise, the standard error of the mean and confidence levels from two-sample t-test is applied and also accounts for serial correlation in the annual means of the simulation (Wilks, 2006). The IAV of surface $\mathrm{Hg}(0)$ concentration is about $0.01 \mathrm{ng} / \mathrm{m}^{3}$ ( $1 \%$ of the mean) over most of the regions in the present-day entailing the longer lifetime of atmospheric $\operatorname{Hg}(0)$. At the same time, average surface air $\mathrm{Hg}(0)$ concentration in northern and southern high latitudes under future climate scenario increase by 5\% and $7 \%$ respectively and these increases are significant at the $95 \%$ confidence level. This is similar to that of Hansen et al. (2015) which predicated a 4\% higher average Arctic air concentration of $\mathrm{Hg}(0)$ in the future climate. In addition, our model results here show that annual mean surface $\mathrm{Hg}(0)$ concentration over United States will increase by $0.05-0.07 \mathrm{ng} / \mathrm{m}^{3}$ in future climate. A previous study by Megaritis et al. (2014) predicted that climate change following IPCC A2 scenario would slightly decrease the $\operatorname{Hg}(0)$ level by up to $0.07 \mathrm{ng} / \mathrm{m} 3$ in summer and less in winter $(<0.01 \mathrm{ng} / \mathrm{m} 3)$ over eastern United States, but the atmospheric chemistry including both gaseous phase and aqueous phase oxidation in the model is different with the chemistry in the present model. In contrast, 2000-2050 changes in land use/land cover both individually and together lead to decrease in $\operatorname{Hg}(0)$ concentration as a result of the enhanced uptake of $\operatorname{Hg}(0)$ by vegetation. Land use and land cover together could drive surface $\operatorname{Hg}(0)$ concentration to decrease by $3 \%$ at the $95 \%$ confidence level in the northern hemisphere although little change was found for the southern hemisphere. The larger decrease in the northern hemisphere reflects the higher vegetation coverage in the northern hemisphere, especially the northern mid-latitudes. 

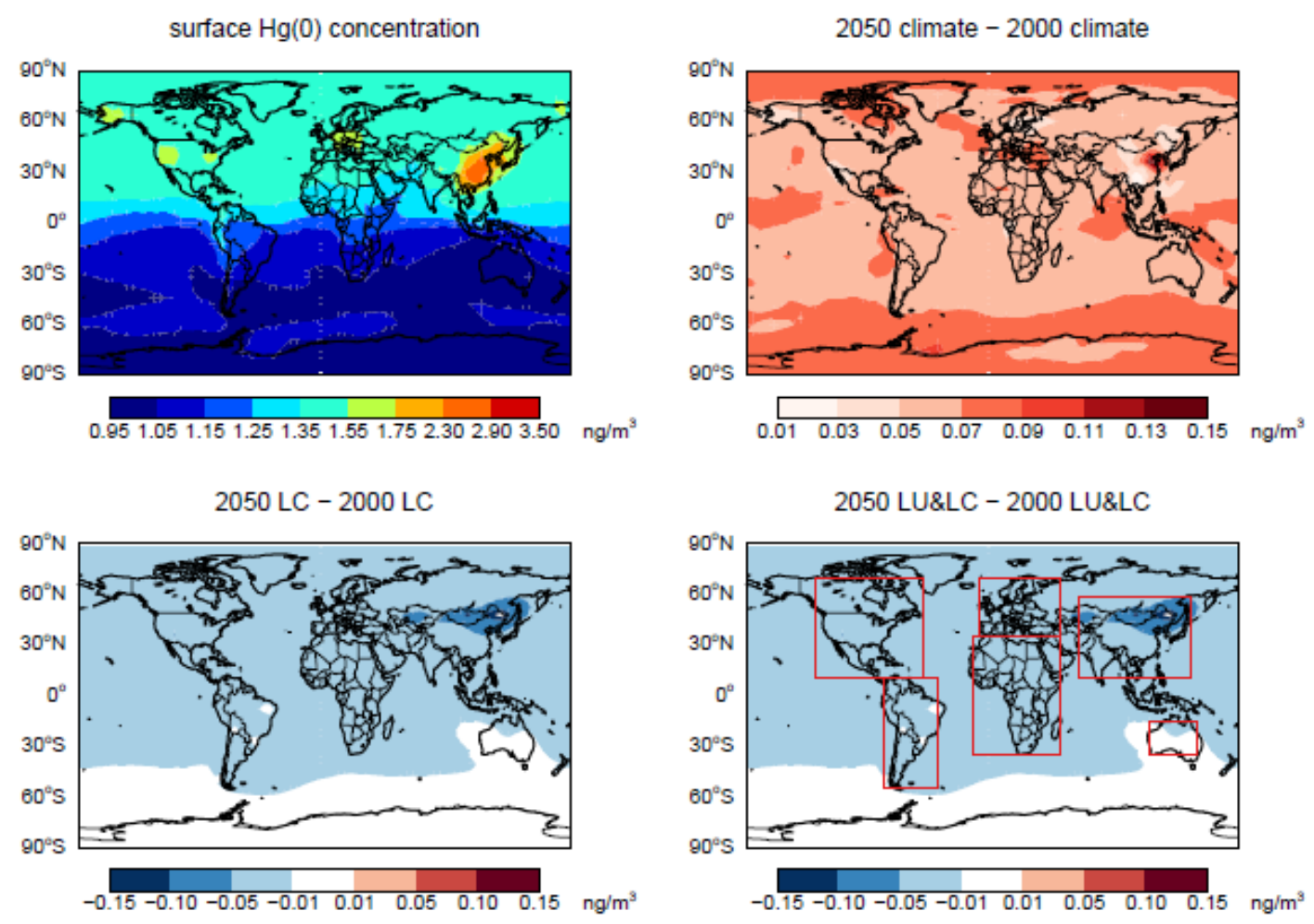

364

365

366

367

368

369

370

371

372

373

374

375

376

377

378

379

Figure 5. Annual mean surface $\operatorname{Hg}(0)$ concentration for the present-day (top left) and the difference due to 2000-2050 climate change (top right), 2000-2050 land cover change (bottom left), 2000-2050 land use/land cover change (bottom right).

The changes in surface $\operatorname{Hg}(\mathrm{II})$ concentration shows greater spatial variability than $\operatorname{Hg}(0)$, reflecting the shorter lifetime of $\mathrm{Hg}$ (II) (Fig. 6). Surface average gaseous phase $\mathrm{Hg}$ (II) concentration over North America is calculated to decrease by $16 \%$ due to the increase in wet deposition. We also find climate change causes surface gas phase $\mathrm{Hg}(\mathrm{II})$ concentration to decrease by $34 \%$ and $17 \%$ significantly over northern and southern high latitudes while no significant changes are found in these regions driven by future land use/land cover change. The decrease is a result of the change in atmospheric chemistry and wet deposition over the high latitudes in the future climate. (Hansen et al., 2015) also found $41 \%$ decrease in average Arctic air concentration of RGM (equivalent to gas phase $\mathrm{Hg}$ (II) in the present study) in the future climate. Surface gaseous phase $\mathrm{Hg}$ (II) concentration is calculated to decrease by $10 \%, 31 \%, 7 \%$ and $10 \%$ in North Pacific (defined as $180-80^{\circ} \mathrm{W}, 25-180^{\circ} \mathrm{E}$ and $30-70^{\circ} \mathrm{N}$ ), North Atlantic (defined as $80-25^{\circ} \mathrm{W}$ and $55-70^{\circ} \mathrm{N}$ ), Middle Atlantic (defined as $80-25^{\circ} \mathrm{W}$ and $25^{\circ} \mathrm{S}-55^{\circ} \mathrm{N}$ ) and 
South Atlantic (defined as $80-25^{\circ} \mathrm{W}$ and $65^{\circ}-25^{\circ} \mathrm{S}$ ), respectively. The decreases are driven by increase in precipitation and suppressed $\operatorname{Hg}(0)$ oxidation in the troposphere. In contrast, land use/land cover change drive surface average gas phase $\mathrm{Hg}(\mathrm{II})$ concentration decreases by $4 \%$ and $12 \%$ in South America and Australia respectively, largely driven by the increase in $\mathrm{Hg}$ (II) dry deposition and these changes are significant at the $95 \%$ confidence level.
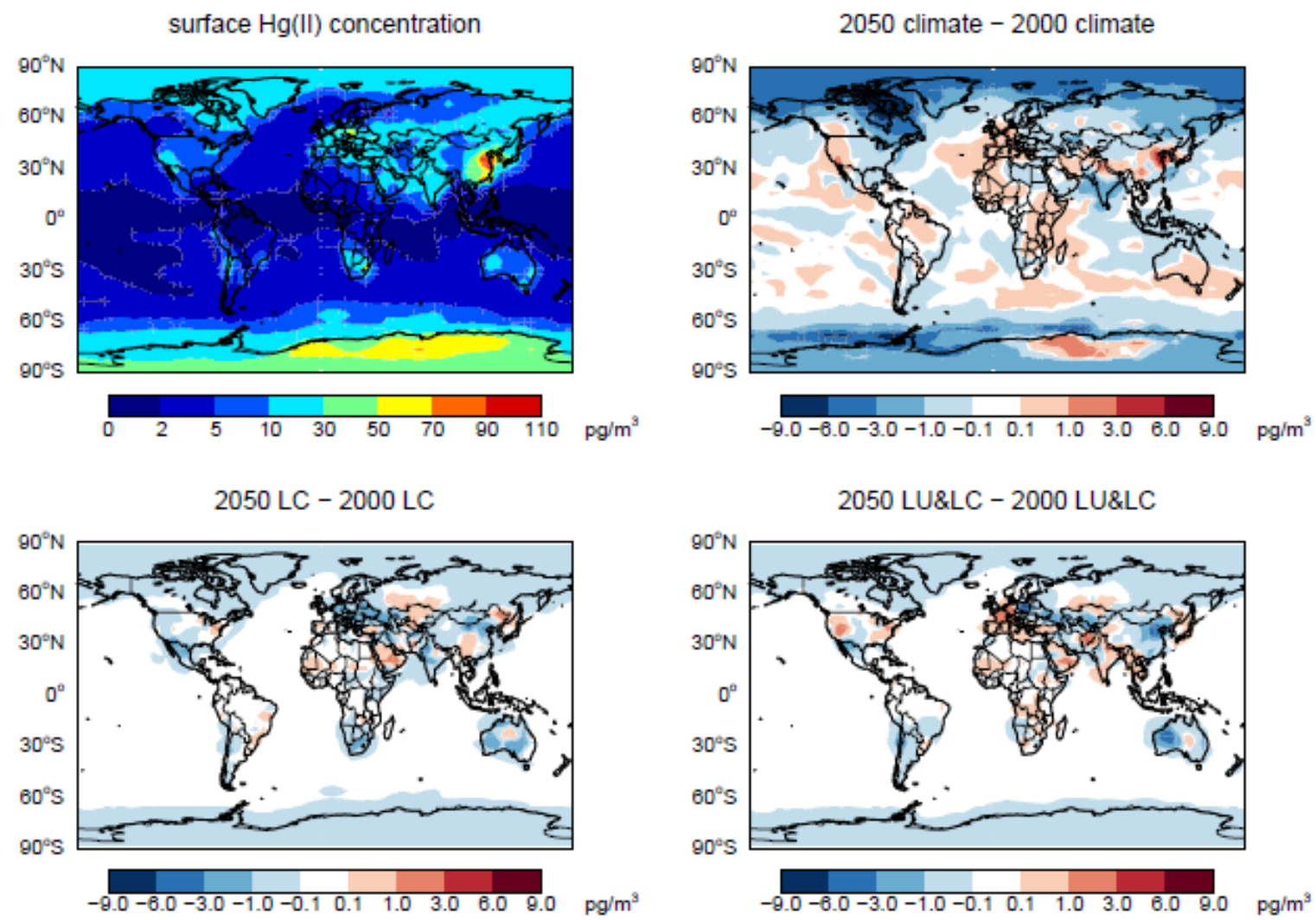

Figure 6. Same as Figure 5, but for annual mean surface gaseous phase $\mathrm{Hg}(\mathrm{II})$ concentration.

\subsection{Effects on the Air-Surface Exchange of Mercury}

390 Air-surface exchanges, including emissions and deposition, are important processes affecting the 391 circulation and distribution of mercury in the global environment. Fig. 7 shows the model 392 calculated annual mean $\operatorname{Hg}(0)$ dry deposition flux for present-day and the perturbations due to 393 2000-2050 changes in climate and land use/land cover, individually and together. The changes in 
future climate alone cause general increase in annual mean $\mathrm{Hg}(0)$ dry deposition flux in most of 395 the continental regions by up to $1.0 \mu \mathrm{g} / \mathrm{m}^{2} / \mathrm{yr}$ (the IAV ranges from 0.06 to $0.2 \mu \mathrm{g} / \mathrm{m}^{2} / \mathrm{yr}$ ). We find the climate-induced change in global annual average $\operatorname{Hg}(0)$ dry deposition velocity is negligible and therefore the increases in $\operatorname{Hg}(0)$ dry deposition flux are mainly driven by the increases in surface $\mathrm{Hg}(0)$ concentrations as discussed in Sec 3.2.
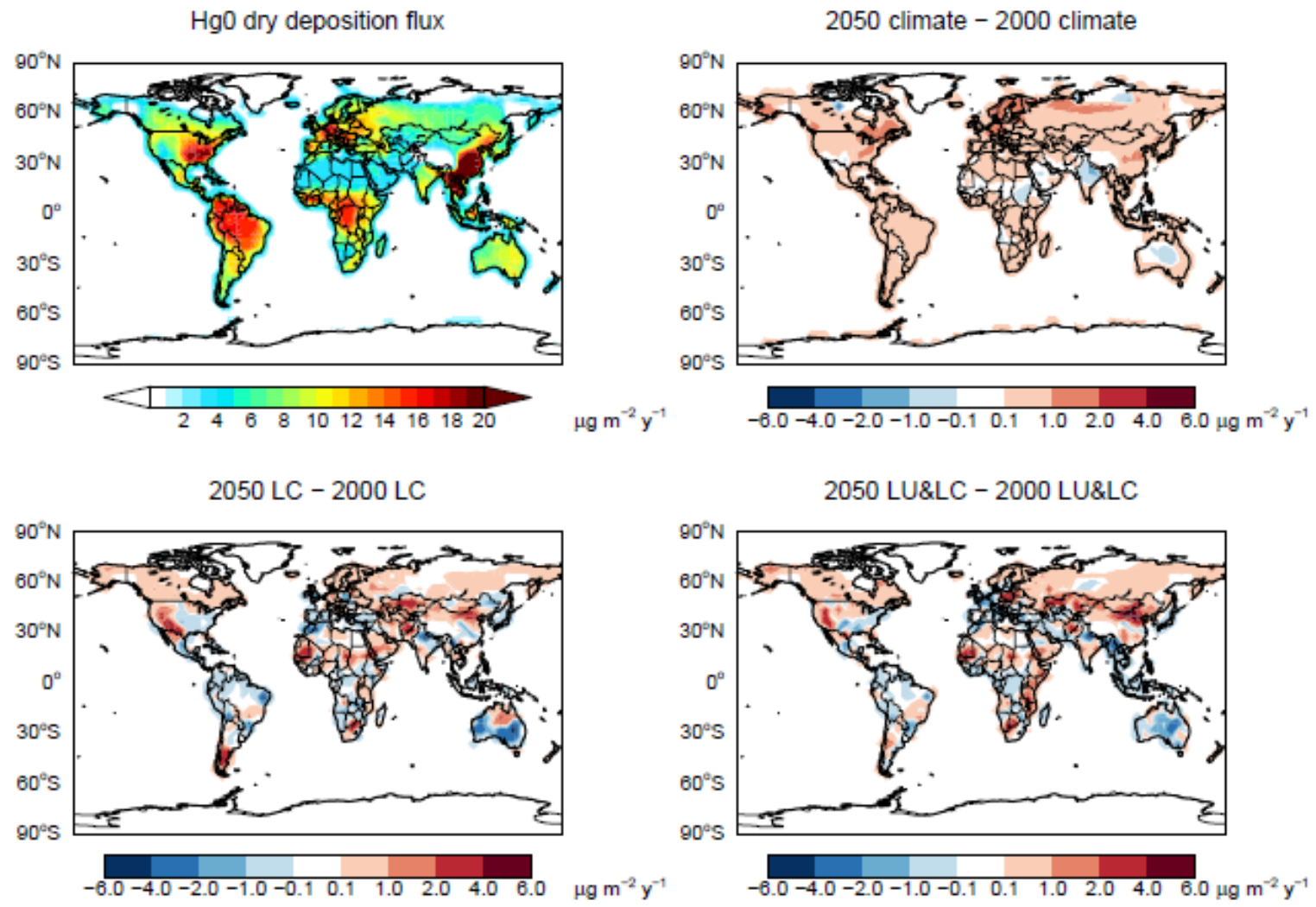

Figure 7. Annual mean $\operatorname{Hg}(0)$ dry deposition flux for the present-day (top left) and the impacts

401 from 2000-2050 climate change (top right), land cover change (bottom left), and the combined land use/land cover change (bottom right).

403 Projected 2000-2050 vegetation changes alone increase annual mean $\mathrm{Hg}(0)$ dry deposition flux 404 in most parts of Northern mid-latitudes, North Africa, Northern Australia and southern part of 405 South America (bottom left panel in Fig. 7). We find large increase in annual mean $\mathrm{Hg}(0) \operatorname{dry}$ 406 deposition flux by up to $6 \mu \mathrm{g} / \mathrm{m}^{2} / \mathrm{yr}$ in western United States, part of North Africa, central Asia 407 and northern China. This change is driven by a 50-80\% increase in $\mathrm{Hg}(0)$ dry deposition velocity 408 over denser vegetation in the future, which is caused by $\mathrm{CO}_{2}$ fertilization and climate change. As discussed in Wu et al. (2012), some conifer forests dominated by needle leaf trees are expected 
to be replaced by temperate forests dominated by broadleaf trees following the 2000-2050 natural vegetation change. Globally, it is simulated that the spatial coverage of temperate broadleaf summer green trees will increase by $\sim 20 \%$ while boreal needle leaf evergreen trees decrease by $\sim 7 \%$. The most significant changes in vegetation cover are found over northern midlatitudes, with $\sim 39 \%$ increase in temperate deciduous broadleaf trees and $\sim 8 \%$ decrease in boreal evergreen needle leaf trees. Furthermore, general increases in LAI are found everywhere except for the subtropical regions in response to changes in vegetation over the 2000-2050 period driven by climate change and $\mathrm{CO}_{2}$ fertilization. Decrease in $\mathrm{Hg}(0)$ dry deposition flux up to $2 \mu \mathrm{g} / \mathrm{m}^{2} / \mathrm{yr}$ are found over eastern United States, part of Amazon forest and southern Australia, driven by decrease in LAI. Overall, surface $\operatorname{Hg}(0)$ dry deposition flux is found to increase significantly by $5 \%, 4 \%, 4 \%$, and $4 \%$ in North America, Europe, Asia and Africa respectively. No significant change is found in South America while decrease by 34\% in found in Australia largely due to the decrease in LAI.

The IPCC A1B scenario (IPCC, 2001; MNP, 2006) projects that agricultural land area will increase over some regions including the eastern United States, South Asia and Central Africa but decrease over East Asia driven by the changes in population, economic development and energy consumption (MNP, 2006). We find that in general the anthropogenic land use change has a smaller impact on mercury deposition when compared to the impact from natural vegetation change (driven by changes in climate and atmospheric $\mathrm{CO}_{2}$ fertilization). When considering the combined effects from natural vegetation change and anthropogenic land use change, decrease in $\operatorname{Hg}(0)$ dry deposition flux over South Asian and middle of central Africa up to $2 \mu \mathrm{g} / \mathrm{m}^{2} / \mathrm{yr}$ are found in response to the decrease in LAI driven by agricultural expansion and deforestation there. The combined effects of land use and land cover cause similar change in surface $\operatorname{Hg}(0)$ dry deposition flux over North America (+4\%), Europe (+3\%) and Africa $(+5 \%)$ compared with that of land cover change alone. The role of vegetation as a source or sink of atmospheric $\operatorname{Hg}(0)$ has been in debate, but more recent assessments show that vegetation acts more as a net sink (Ericksen et al., 2003; Hartman et al., 2009; Rutter et al., 2011). Our results here suggest the strong sensitivity of $\operatorname{Hg}(0)$ dry deposition to future land use/land cover change in spite of large uncertainties associated with the atmosphere-foliar exchange flux measurement (Agnan et al., 2016; Zhu et al., 2016). It further emphasizes the importance of better constraint on atmosphere-surface exchange of $\operatorname{Hg}(0)$. 
441 Fig. 8 shows the model calculated annual mean total mercury (gaseous phase $\mathrm{Hg}(\mathrm{II})+$ particulate

442 phase $\mathrm{Hg}(\mathrm{II})$ ) wet deposition flux for the present-day and the perturbations due to 2000-2050

443 climate change as well as the changes in precipitation. The changes in total mercury wet

444 deposition flux are well correlated with the changes in precipitation in the future climate (lower

445 right panel of Fig. 8), with the noticeable exception of the tropical region. With abundant

446 precipitation in the tropical rain belt, wet scavenging is nearly insensitive to the increases in

447 precipitation, so the suppressed oxidation of $\mathrm{Hg}(0)$ to $\mathrm{Hg}(\mathrm{II})$ leads to decreased wet deposition of

$448 \mathrm{Hg}(\mathrm{II})$ in the tropics. We find $6 \%$ and $7 \%$ at the $95 \%$ confidence level the increase in annual

449 mean mercury wet deposition flux in Africa and South America while no significant changes are

450 found in North America, Europe, Asia and Australia (Present-day IAV of annual mean mercury

451 wet deposition flux is about $2 \%-3 \%$ of the mean). Furthermore, annual mean mercury wet

452 deposition flux decreases by 3\% in Middle Atlantic while the changes in North Pacific, North

453 Atlantic and South Atlantic are not significant. Annual mean mercury wet deposition flux to the

454 northern and southern high latitude increase by $7 \%$ and $8 \%$ respectively largely driven by the

455 increase in precipitation. The annual total precipitation increases by $21 \%$ and $11 \%$ respectively. 

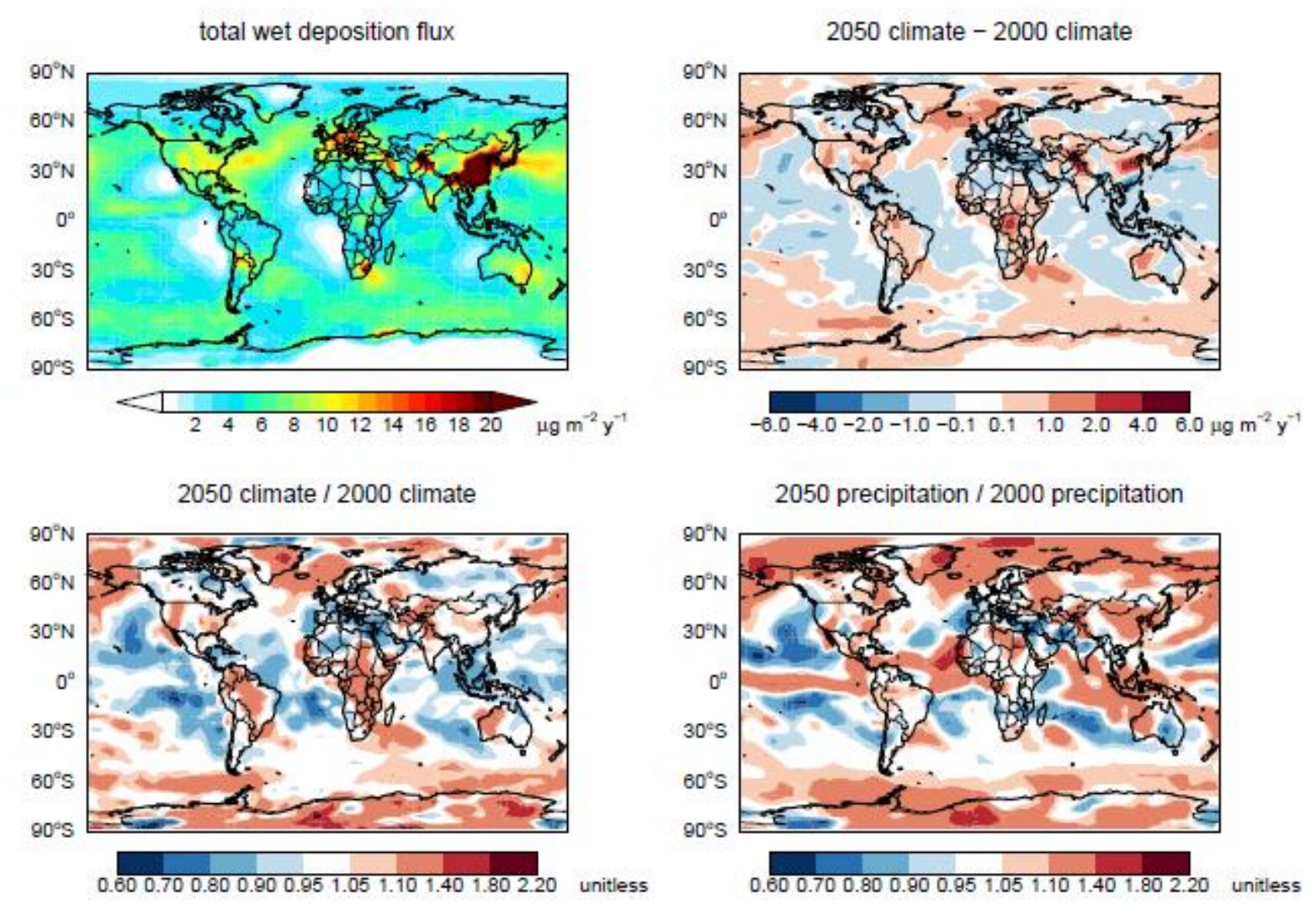

Figure 8. Annual mean total wet deposition flux for the present-day (top left) and the difference 458 due to 2000-2050 climate change (top right), the ratio due to 2000-2050 climate change (bottom 459 left), annual mean total surface precipitation ratio due to 2000-2050 climate change (bottom 460 right).

461 We further examine the impacts of changes in climate and land use/land cover on the gross 462 deposition of mercury (dry deposition, wet deposition plus sea salt uptake of gaseous $\mathrm{Hg}(\mathrm{II})$ ).

463 Fig. 9 shows the model calculated annual mean gross mercury deposition flux for the present-day 464 and the perturbations due to 2000-2050 changes in climate, natural vegetation and agricultural 465 land use. Climate change leads to general increases in gross deposition flux over the continental 466 regions and decreases over most of the ocean areas in northern hemisphere, mainly following the 467 changes in mercury wet deposition as discussed above. Specifically, we find annual mean gross 468 mercury deposition flux increases by 3\% 3\%, 4\%, 4\% and 3\% in North America, Asia, Africa, 469 South America and Australia, respectively and these changes are statistically significant at the $47095 \%$ confidence level. No significant changes are found in and Europe. Annual mean gross 
471 mercury deposition flux is only found to decrease significantly by $5 \%$ in Middle Atlantic Ocean

472 basin while no significant changes are found in North Pacific, North Atlantic, South Atlantic,

473 northern and southern high latitudes. Our results here for the northern high latitudes is different

474 from Hansen et al. (2015) which followed SRES A1B (Nakicenovic et al., 2000) for future

475 climate (2090-2100) $\mathrm{Hg}$ simulation using a different $\mathrm{Hg}$ model. (Hansen et al., 2015) found that

476 the total deposition of $\mathrm{Hg}$ to the Arctic Circle $\left(66.5^{\circ} \mathrm{N}\right)$ was significantly $18 \%$ lower in the future

477 climate than the present-day climate, mainly due to the lower RGM air concentrations. In

478 response to the 2000-2050 changes in land use/land cover, the gross deposition of mercury is

479 projected to increase over most continental regions but decrease over oceans. This implies that,

480 due to the enhanced uptake of mercury associated with denser vegetation in the 2050s, a larger

481 fraction of mercury would be accumulated in the terrestrial reservoir rather than the ocean

482 reservoir. This has significant implications for policies as atmospheric deposition of mercury

483 serves as the dominant source of mercury inputs to open ocean regions (Mason and Sheu, 2002;

484 Soerensen et al., 2010; Sunderland and Mason, 2007).
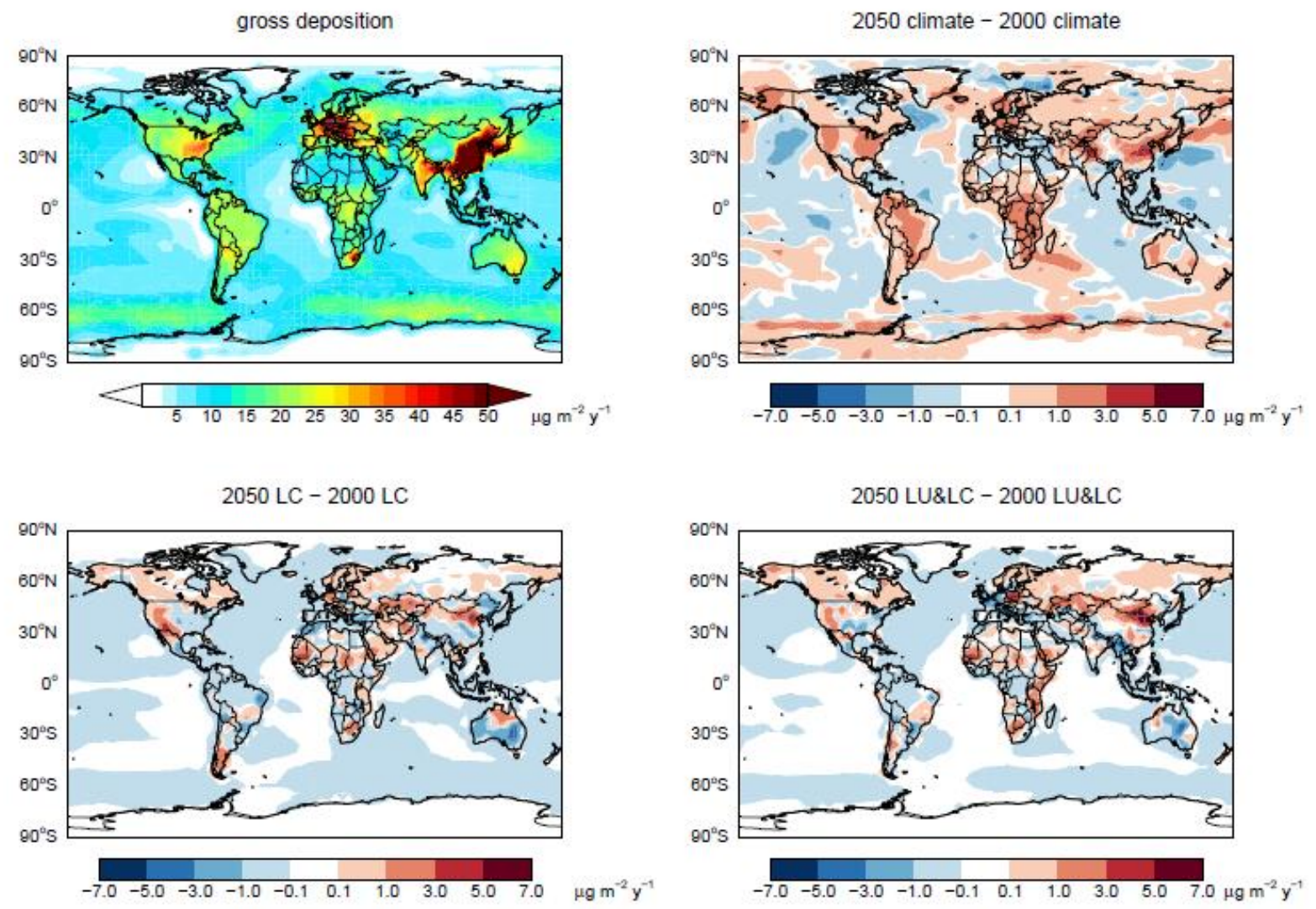

Figure 9. Same as Figure 7, but for total $(\mathrm{Hg}(0)+\mathrm{Hg}(\mathrm{II}))$ mercury deposition flux. 


\subsection{Effects on the Global and Regional Mercury Budget}

489 Table 1a and Table $1 \mathrm{~b}$ shows the global and regional total $\operatorname{Hg}(0)$ dry deposition and total wet deposition of gaseous and particulate phase $\mathrm{Hg}$ (II). Climate change impacts global mercury cycling through different channels. First of all, climate change could impact the air-surface exchange process. We find that climate change causes $\operatorname{Hg}(0)$ dry deposition to increase significantly in most of the continental regions and globally mainly driven by the increase in surface $\operatorname{Hg}(0)$ concentration. The global total uptake of mercury by sea salt aerosol is found to decrease by $8 \%$ (not shown in the table), mainly driven by the decrease in atmospheric $\mathrm{Hg}$ (II) concentration. Total wet deposition are calculated to increase by $5 \%$ and $6 \%$ in South America and Africa and no significant change is found globally. In addition, climate change potentially influences secondary emission of $\operatorname{Hg}(0)$. We find a $9 \%$ (not shown in the table) decrease in global mercury emissions from snow, which is mainly due to the decreases in snow cover in a warmer climate. The decrease in re-emission of $\operatorname{Hg}(0)$ together with the increase in $\operatorname{Hg}(0)$ dry deposition causes the global net emission of $\mathrm{Hg}(0)$ from terrestrial surface in the 2050 climate to 502 decrease by $11 \%$.

503 Changes in vegetation in the future primarily affect mercury dry deposition over the continental regions. Global total $\mathrm{Hg}(0)$ dry deposition is calculated to increase by $3 \%$ as a result of combined effects from anthropogenic land use change and natural vegetation changes over the 2000-2050 period. This is largely driven by the increase in LAI, which enhances the vegetation uptake of $\mathrm{Hg}(0)$. We also find the 2000-2050 changes in land use and land cover cause global net emission of $\mathrm{Hg}(0)$ to decrease by $9 \%$ mainly as a result of the augmentation in $\mathrm{Hg}(0)$ dry deposition.

Table 1a. Global and regional total $\operatorname{Hg}(0)$ dry deposition for the present-day and the 511 perturbations due to 2000-2050 changes in climate and land use/land cover. The regions are 512 those defined in $\operatorname{Sec} 3.2$.

$\begin{array}{ccc}2000 \text { Climate }+ & 2050 \text { Climate }+ & 2000 \text { Climate }+ \\ 2000 \text { LU\&LC } & 2000 \text { LU\&LC } & 2000 \text { LU\&LC }\end{array}$




\begin{tabular}{cccc}
\hline North America & $161^{\mathrm{a}}$ & $171(+6 \%)^{\mathrm{b}}$ & $172(+7 \%)$ \\
Europe & 114 & $124(+7 \%)$ & $117(+3 \%)$ \\
South America & 218 & $224(+7 \%)$ & 217 \\
Asia & 223 & $236(+4 \%)$ & $236(+6 \%)$ \\
Africa & 261 & 267 & $275(+5 \%)$ \\
global & 1440 & $1508(+5 \%)$ & $1480(+3 \%)$
\end{tabular}

$513{ }^{a}$ Units are in $\mathrm{Mg} / \mathrm{yr} .{ }^{b}$ Numbers in the parentheses are the percent changes at the $95 \%$ confidence 514 level and also significant comparing with the respective IAV of present-day.

524 Table 1b. Same as Table 1a, but for total wet deposition of gaseous and particulate phase $\mathrm{Hg}$ (II).

\begin{tabular}{cccc}
\hline & $\begin{array}{c}\text { 2000 Climate }+ \\
\text { 2000 LU\&LC }\end{array}$ & $\begin{array}{c}\text { 2050 Climate }+ \\
\text { 2000 LU\&LC }\end{array}$ & $\begin{array}{c}\text { 2000 Climate + } \\
\text { 2000 LU\&LC }\end{array}$ \\
\hline North America & 133 & 136 & 131 \\
Europe & 95 & 90 & 94 \\
South America & 100 & $106(+6 \%)$ & 98 \\
Asia & 297 & 307 & 293 \\
Africa & 167 & $176(+5 \%)$ & 166 \\
global & 2918 & 2947 & 2882 \\
\hline
\end{tabular}

526 No significant change is found in global ocean evasion in the future climate but significant 527 regional changes are found. Ocean evasion from the Arctic Ocean and Antarctic Ocean increase 528 by $29 \%$ and $14 \%$ respectively, largely affected by increase in temperature with Arctic increasing 
529 by $3.5 \mathrm{~K}$ and Antarctic 1.6K. No significant changes are found for North Pacific Ocean and 530 Atlantic Ocean (North Atlantic + Middle Atlantic + South Atlantic). We note our results here 531 only show partial sensitivity of air-surface ocean exchange to meteorology change such as 532 temperature. Some recent offline global ocean models (Zhang et al., 2014a; Zhang et al., 2014b) 533 have been developed to study the anthropogenic influence on mercury levels in the ocean, but 534 have not been coupled to atmospheric chemical transport model. In addition, sea ice cover plays 535 an important role in air-ocean exchange of $\operatorname{Hg}(0)$ (Chen et al., 2015; Fisher et al., 2012; Zhang et 536 al., 2015) and it is not explicitly simulated in the model used in this study.

537 Climate change could affect the atmospheric mercury redox chemistry mainly through the 538 change in temperature. The increase in secondary emission of $\operatorname{Hg}(0)$ and the increase in in-cloud 539 of reduction of $\mathrm{Hg}(\mathrm{II})$ together lead to an increase of $7 \%$ increase of global $\mathrm{Hg}(0)$ burden as seen 540 in Table 2. Correspondingly, the global average atmospheric lifetime of mercury is calculated to 541 increases by $4 \%$ which could have potential effects on the long range transport of mercury.

545 Table 2. Global atmospheric mercury burden, oxidation and reduction, and atmospheric lifetime 546 of mercury for the present-day and the perturbations due to 2000-2050 changes in climate and 547 land use/land cover.

\begin{tabular}{llll}
\hline & $\begin{array}{l}\text { 2000 climate } \\
+2000 \text { LU\&LC }\end{array}$ & $\begin{array}{l}\text { 2050 climate } \\
+2000 \text { LU\&LC }\end{array}$ & $\begin{array}{l}\text { 2000 climate } \\
+2050 \text { LU\&LC }\end{array}$ \\
\hline Global $\mathrm{Hg}(0)$ burden $\left(\mathrm{Mg} \mathrm{yr}^{-1}\right)$ & 3990 & $4260(+7 \%)^{\mathrm{a}}$ & 3940 \\
Gross oxidation of $\mathrm{Hg}(0)$ & 5857 & 5921 & 5783 \\
Gross reduction of $\mathrm{Hg}(\mathrm{II})$ & 1839 & $1925(+5 \%)$ & 1815 \\
Atmospheric lifetime of mercury $(\mathrm{yr})$ & 0.78 & $0.81(+4 \%)$ & 0.77 \\
\hline
\end{tabular}

\footnotetext{
${ }^{a}$ Numbers in the parentheses are the percent changes at the 95\% confidence level and also significant comparing with the respective IAV of present-day.
} 


\section{Conclusions and Discussion}

549 We investigate the potential impacts on atmospheric mercury from 2000-2050 changes in climate and land use/land cover by combining a global chemical transport model (GEOS-Chem), a general circulation model (GISS GCM 3), and a global dynamic vegetation model (LPJ).

Our results demonstrate the potential impacts from climate change on atmospheric mercury through different processes. First, the future changes in precipitation have important implications for the spatial distribution of total mercury wet deposition. Atmospheric mercury redox chemistry is also affected by climate change through changes in temperature and cloud water with global mercury reduction increasing by $5 \%$. The increase in atmospheric mercury reduction cause surface $\operatorname{Hg}(0)$ concentration to increase globally with significant changes occurred over most continental regions and ocean reasons. As a consequence, $\mathrm{Hg}(0)$ dry deposition flux increases globally. In addition, climate change can significantly affect secondary mercury emissions. Reduced snow coverage causes $9 \%$ global decrease in $\operatorname{Hg}(0)$ emissions from snow. The future changes in surface ocean temperature and atmospheric deposition driven by climate change also result in significant changes in atmospheric-surface ocean exchange of atmospheric $\operatorname{Hg}(0)$.

Land use and land cover changes lead to general increases in $\operatorname{Hg}(0)$ dry deposition flux with

565 large spatial variations. This is largely due to the augmented $\operatorname{Hg}(0)$ dry deposition velocity driven by changes in vegetation type and density. We find general increase in annual mean $\operatorname{Hg}(0)$

567 dry deposition flux in northern mid-latitudes, which reflects the prevailing changes of vegetation.

568 The largest increases in the annual mean $\mathrm{Hg}(0)$ dry deposition flux by up to $6 \mu \mathrm{g} / \mathrm{m}^{2} / \mathrm{yr}$ are found 569 over western United States, part of North Africa, central Asia and northern China. The global total $\mathrm{Hg}(0)$ dry deposition in the 2050 s will increase by $3 \%$ driven by changes in natural 571 vegetation and anthropogenic land use.

572 Our results here show significant change in surface $\mathrm{Hg}(0)$ and gaseous $\mathrm{Hg}(\mathrm{II})$ concentration in 573 the Arctic Ocean driven by future change in climate. Previous study by Fisher et al. (2013) has 574 shown that the larger interannual variability in atmospheric $\mathrm{Hg}$ in several observation sites in the 575 Arctic is driven by environmental factors such as temperature and potentially climate change 576 over the past 30 years. Other studies also suggest the biogeochemical cycling of $\mathrm{Hg}$ in the Arctic 577 Ocean is sensitive to ongoing climate variability (Krabbenhoft and Sunderland, 2013; Soerensen 
et al., 2016; Stern et al., 2012). Our results here illustrate the potential effects of future climate change on atmospheric mercury in the Arctic Ocean and the discrepancy between model results in our work and that of Hansen et al. (2015) requires more modeling efforts to reduce the uncertainty.

Our results show that gross mercury deposition flux could increase over most continental regions driven by changes in 2000-2050 climate and land use/land cover. This implies increased mercury uptake by the terrestrial system which decreases the mobilization of $\mathrm{Hg}$. However, deep ocean and soil reservoirs are not explicitly simulated in our model and we are unable to evaluate the long-term impact on soil and deep ocean reservoir of mercury. This study does not account for the potential effects on biomass burning emissions of mercury associated with the changes in climate and land use/land cover. Some preliminary results from an ongoing research (Kumar et al., 2016) indicate these effects can be significant for some regions. There are also substantial uncertainties associated with the model treatment of air-surface exchange (Selin et al., 2008; Soerensen et al., 2010; Song et al., 2015) and atmospheric chemistry of mercury (Holmes et al., 2006; Holmes et al., 2010) as well as the mercury measurement (Jaffe et al., 2014). These uncertainties can significantly affect our projection on the long-term evolution of atmospheric mercury in the coming decades. More mercury measurement and model development efforts are needed to reduce these uncertainties (Gustin et al., 2015).

\section{Acknowledgements}

This work was supported by the National Science Foundation (grant \#1313755) and U.S. EPA (grant \#83518901). We are grateful to Dr. Jed Kaplan (University of Lausanne) for providing the LPJ vegetation data. We thank Dr. Noelle E. Selin (MIT) for helpful discussion on the atmospheric mercury chemistry in the model. We also thank Dr. Anne L. Soerensen (Stockholm University) and Dr. Jenny A. Fisher (University of Wollongong) for helpful discussion on airocean exchange of mercury in the model. Superior, a high performance computing cluster at Michigan Technological University, was used in obtaining results presented in this publication.

\section{Reference}


Agnan, Y., Le Dantec, T., Moore, C. W., Edwards, G. C., and Obrist, D.: New Constraints on Terrestrial Surface-Atmosphere Fluxes of Gaseous Elemental Mercury Using a Global Database, Environmental science \& technology, 50, 507-524, 10.1021/acs.est.5b04013, 2016.

Almeida, M. D., Marins, R. V., Paraquetti, H. H. M., Bastos, W. R., and Lacerda, L. D.: Mercury degassing from forested and open field soils in Rondonia, Western Amazon, Brazil, Chemosphere, 77, 60-66, 10.1016/j.chemosphere.2009.05.018, 2009.

Amos, H. M., Jacob, D. J., Holmes, C. D., Fisher, J. A., Wang, Q., Yantosca, R. M., Corbitt, E. S., Galarneau, E., Rutter, A. P., Gustin, M. S., Steffen, A., Schauer, J. J., Graydon, J. A., St Louis, V. L., Talbot, R. W., Edgerton, E. S., Zhang, Y., and Sunderland, E. M.: Gas-particle partitioning of atmospheric $\mathrm{Hg}(\mathrm{II})$ and its effect on global mercury deposition, Atmospheric Chemistry and Physics, 12, 591-603, 10.5194/acp-12591-2012, 2012.

Amos, H. M., Jacob, D. J., Streets, D. G., and Sunderland, E. M.: Legacy impacts of all-time anthropogenic emissions on the global mercury cycle, Global Biogeochemical Cycles, 27, 410-421, 10.1002/gbc.20040, 2013.

Andersson, M. E., Gardfeldt, K., Wangberg, I., and Stromberg, D.: Determination of Henry's law constant for elemental mercury, Chemosphere, 73, 587-592, 10.1016/j.chemosphere.2008.05.067, 2008.

Bachelet, D., Neilson, R. P., Lenihan, J. M., and Drapek, R. J.: Climate change effects on vegetation distribution and carbon budget in the United States, Ecosystems, 4, 164-185, 10.1007/s10021-001-00027, 2001.

Bash, J. O., Bresnahan, P., and Miller, D. R.: Dynamic surface interface exchanges of mercury: A review and compartmentalized modeling framework, Journal of Applied Meteorology and Climatology, 46, 1606-1618, 10.1175/jam2553.1, 2007.

Bash, J. O.: Description and initial simulation of a dynamic bidirectional air-surface exchange model for mercury in Community Multiscale Air Quality (CMAQ) model, Journal of Geophysical ResearchAtmospheres, 115, 10.1029/2009jd012834, 2010.

Bergan, T., Gallardo, L., and Rodhe, H.: Mercury in the global troposphere: a three-dimensional model study, Atmospheric Environment, 33, 1575-1585, 10.1016/s1352-2310(98)00370-7, 1999.

Bey, I., Jacob, D. J., Yantosca, R. M., Logan, J. A., Field, B. D., Fiore, A. M., Li, Q. B., Liu, H. G. Y., Mickley, L. J., and Schultz, M. G.: Global modeling of tropospheric chemistry with assimilated meteorology: Model description and evaluation, Journal of Geophysical Research-Atmospheres, 106, 23073-23095, 2001.

Blackwell, B. D., Driscoll, C. T., Maxwell, J. A., and Holsen, T. M.: Changing climate alters inputs and pathways of mercury deposition to forested ecosystems, Biogeochemistry, 119, 215-228, 10.1007/s10533-014-9961-6, 2014.

Chen, L., Zhang, Y., Jacob, D. J., Soerensen, A. L., Fisher, J. A., Horowitz, H. M., Corbitt, E. S., and Wang, $X .:$ A decline in Arctic Ocean mercury suggested by differences in decadal trends of atmospheric mercury between the Arctic and northern midlatitudes, Geophys. Res. Lett., 42, 6076-6083, 10.1002/2015gl064051, 2015.

Choi, A. L., and Grandjean, P.: Methylmercury exposure and health effects in humans, Environmental Chemistry, 5, 112-120, 10.1071/en08014, 2008.

Corbitt, E. S., Jacob, D. J., Holmes, C. D., Streets, D. G., and Sunderland, E. M.: Global Source-Receptor Relationships for Mercury Deposition Under Present-Day and 2050 Emissions Scenarios, Environmental Science \& Technology, 45, 10477-10484, 10.1021/es202496y, 2011. 
Cox, P. M., Betts, R. A., Collins, M., Harris, P. P., Huntingford, C., and Jones, C. D.: Amazonian forest dieback under climate-carbon cycle projections for the 21st century, Theoretical and Applied Climatology, 78, 137-156, 10.1007/s00704-004-0049-4, 2004.

Cramer, W., Bondeau, A., Woodward, F. I., Prentice, I. C., Betts, R. A., Brovkin, V., Cox, P. M., Fisher, V., Foley, J. A., Friend, A. D., Kucharik, C., Lomas, M. R., Ramankutty, N., Sitch, S., Smith, B., White, A., and Young-Molling, C.: Global response of terrestrial ecosystem structure and function to $\mathrm{CO} 2$ and climate change: results from six dynamic global vegetation models, Glob. Change Biol., 7, 357-373, 10.1046/j.1365-2486.2001.00383.x, 2001.

Eckley, C. S., and Branfireun, B.: Gaseous mercury emissions from urban surfaces: Controls and spatiotemporal trends, Applied Geochemistry, 23, 369-383, 10.1016/j.apgeochem.2007.12.008, 2008.

Ericksen, J. A., Gustin, M. S., Schorran, D. E., Johnson, D. W., Lindberg, S. E., and Coleman, J. S.: Accumulation of atmospheric mercury in forest foliage, Atmospheric Environment, 37, 1613-1622, 10.1016/s1352-2310(03)00008-6, 2003.

Ericksen, J. A., and Gustin, M. S.: Foliar exchange of mercury as a function of soil and air mercury concentrations, Science of the Total Environment, 324, 271-279, 10.1016/j.scitotenv.200310.034, 2004.

Ericksen, J. A., Gustin, M. S., Xin, M., Weisberg, P. J., and Fernandez, G. C. J.: Air-soil exchange of mercury from background soils in the United States, Science of the Total Environment, 366, 851-863, 10.1016/j.scitotenv.2005.08.019, 2006.

Fain, X., Grangeon, S., Bahlmann, E., Fritsche, J., Obrist, D., Dommergue, A., Ferrari, C. P., Cairns, W., Ebinghaus, R., Barbante, C., Cescon, P., and Boutron, C.: Diurnal production of gaseous mercury in the alpine snowpack before snowmelt, Journal of Geophysical Research-Atmospheres, 112, 10.1029/2007jd008520, 2007.

Fain, X., Ferrari, C. P., Dommergue, A., Albert, M., Battle, M., Arnaud, L., Barnola, J. M., Cairns, W., Barbante, C., and Boutron, C.: Mercury in the snow and firn at Summit Station, Central Greenland, and implications for the study of past atmospheric mercury levels, Atmospheric Chemistry and Physics, 8, 3441-3457, 2008.

Fisher, J. A., Jacob, D. J., Soerensen, A. L., Amos, H. M., Steffen, A., and Sunderland, E. M.: Riverine source of Arctic Ocean mercury inferred from atmospheric observations, Nature Geoscience, 5, 499-504, 10.1038/ngeo1478, 2012.

Fisher, J. A., Jacob, D. J., Soerensen, A. L., Amos, H. M., Corbitt, E. S., Streets, D. G., Wang, Q., Yantosca, R. M., and Sunderland, E. M.: Factors driving mercury variability in the Arctic atmosphere and ocean over the past 30 years, Global Biogeochemical Cycles, 27, 1226-1235, 10.1002/2013gb004689, 2013.

Fu, X., Feng, X., Sommar, J., and Wang, S.: A review of studies on atmospheric mercury in China, Science of the Total Environment, 421, 73-81, 10.1016/j.scitotenv.2011.09.089, 2012a.

Fu, X., Feng, X., Zhang, H., Yu, B., and Chen, L.: Mercury emissions from natural surfaces highly impacted by human activities in Guangzhou province, South China, Atmospheric Environment, 54, 185-193, 10.1016/j.atmosenv.2012.02.008, 2012b.

Ganzeveld, L., Bouwman, L., Stehfest, E., van Vuuren, D. P., Eickhout, B., and Lelieveld, J.: Impact of future land use and land cover changes on atmospheric chemistry-climate interactions, Journal of Geophysical Research-Atmospheres, 115, 10.1029/2010jd014041, 2010. 
Gao, W., and Wesely, M. L.: MODELING GASEOUS DRY DEPOSITION OVER REGIONAL SCALES WITH SATELLITE-OBSERVATIONS .1. MODEL DEVELOPMENT, Atmospheric Environment, 29, 727-737, 10.1016/1352-2310(94)00284-r, 1995.

Gratz, L. E., Keeler, G. J., and Miller, E. K.: Long-term relationships between mercury wet deposition and meteorology, Atmospheric Environment, 43, 6218-6229, 10.1016/j.atmosenv.2009.08.040, 2009.

Gustin, M. S., Engle, M., Ericksen, J., Lyman, S., Stamenkovic, J., and Xin, M.: Mercury exchange between the atmosphere and low mercury containing substrates, Applied Geochemistry, 21, 1913-1923, 10.1016/j.apgeochem.2006.08.007, 2006.

Gustin, M. S., Lindberg, S. E., and Weisberg, P. J.: An update on the natural sources and sinks of atmospheric mercury, Applied Geochemistry, 23, 482-493, 10.1016/j.apgeochem.2007.12.010, 2008.

Gustin, M. S., Amos, H. M., Huang, J., Miller, M. B., and Heidecorn, K.: Measuring and modeling mercury in the atmosphere: a critical review, Atmospheric Chemistry and Physics, 15, 5697-5713, 10.5194/acp15-5697-2015, 2015.

Hansen, K. M., Christensen, J. H., and Brandt, J.: The Influence of Climate Change on Atmospheric Deposition of Mercury in the Arctic-A Model Sensitivity Study, International Journal of Environmental Research and Public Health, 12, 11254-11268, 10.3390/ijerph120911254, 2015.

Hanson, P. J., Lindberg, S. E., Tabberer, T. A., Owens, J. G., and Kim, K. H.: FOLIAR EXCHANGE OF MERCURY-VAPOR - EVIDENCE FOR A COMPENSATION POINT, Water Air and Soil Pollution, 80, 373-382, 10.1007/bf01189687, 1995.

Hartman, J. S., Weisberg, P. J., Pillai, R., Ericksen, J. A., Kuiken, T., Lindberg, S. E., Zhang, H., Rytuba, J. J., and Gustin, M. S.: Application of a Rule-Based Model to Estimate Mercury Exchange for Three Background Biomes in the Continental United States, Environmental Science \& Technology, 43, 49894994, 10.1021/es900075q, 2009.

Holmes, C. D., Jacob, D. J., and Yang, X.: Global lifetime of elemental mercury against oxidation by atomic bromine in the free troposphere, Geophys. Res. Lett., 33, 10.1029/2006gl027176, 2006.

Holmes, C. D., Jacob, D. J., Corbitt, E. S., Mao, J., Yang, X., Talbot, R., and Slemr, F.: Global atmospheric model for mercury including oxidation by bromine atoms, Atmospheric Chemistry and Physics, 10, 12037-12057, 10.5194/acp-10-12037-2010, 2010.

Holmes, C. D., Krishnamurthy, N. P., Caffrey, J. M., Landing, W. M., Edgerton, E. S., Knapp, K. R., and Nair, U. S.: Thunderstorms increase mercury wet deposition Environ. Sci. Technol., in review, 2016.

Hossaini, R., Mantle, H., Chipperfield, M. P., Montzka, S. A., Hamer, P., Ziska, E., Quack, B., Krueger, K., Tegtmeier, S., Atlas, E., Sala, S., Engel, A., Boenisch, H., Keber, T., Oram, D., Mills, G., Ordonez, C., SaizLopez, A., Warwick, N., Liang, Q., Feng, W., Moore, E., Miller, B. R., Marecal, V., Richards, N. A. D., Dorf, M., and Pfeilsticker, K.: Evaluating global emission inventories of biogenic bromocarbons, Atmospheric Chemistry and Physics, 13, 11819-11838, 10.5194/acp-13-11819-2013, 2013.

Houghton, R. A., Skole, D. L., Nobre, C. A., Hackler, J. L., Lawrence, K. T., and Chomentowski, W. H.: Annual fluxes or carbon from deforestation and regrowth in the Brazilian Amazon, Nature, 403, 301-304, 10.1038/35002062, 2000.

Hughes, C., Johnson, M., von Glasow, R., Chance, R., Atkinson, H., Souster, T., Lee, G. A., Clarke, A., Meredith, M., Venables, H. J., Turner, S. M., Malin, G., and Liss, P. S.: Climate-induced change in biogenic bromine emissions from the Antarctic marine biosphere, Global Biogeochemical Cycles, 26, 10.1029/2012gb004295, 2012. 
IMAGE-Team: The IMAGE 2.2 implementation of the SRES scenarios. A comprehensive analysis of emissions, climate change and impacts in the 21st century, RIVM CD-ROM publication 481508018, Bilthoven, the Netherlands500110001, 2001.

IPCC: Climate Change 2001: The Scientific Basis, contribution of Working Group I to the Third Assessment Report of the Intergovernmental Panel on Climate Change, IPCC, edited by: Houghton, J. T., Ding, Y., Griggs, D. J., Noguer, M., van der, P. J. Linden, Dai, X., Maskell, K., and Johnson, C. A., Cambridge University Press, Cambridge, United Kingdom and New York, NY, USA, 881 pp. pp., 2001.

Jaffe, D. A., Lyman, S., Amos, H. M., Gustin, M. S., Huang, J., Selin, N. E., Levin, L., ter Schure, A., Mason, R. P., Talbot, R., Rutter, A., Finley, B., Jaegle, L., Shah, V., McClure, C., Arnbrose, J., Gratz, L., Lindberg, S., Weiss-Penzias, P., Sheu, G.-R., Feddersen, D., Horvat, M., Dastoor, A., Hynes, A. J., Mao, H., Sonke, J. E., Slemr, F., Fisher, J. A., Ebinghaus, R., Zhang, Y., and Edwards, G.: Progress on Understanding Atmospheric Mercury Hampered by Uncertain Measurements, Environmental Science \& Technology, 48, 7204-7206, 10.1021/es5026432, 2014.

Krabbenhoft, D. P., and Sunderland, E. M.: Global Change and Mercury, Science, 341, 1457-1458, 10.1126/science.1242838, 2013.

Kumar, A., Wu, S., and Huang, Y.: Impacts of present-2050 land cover change on $\mathrm{Hg}$ wildfire emissions, manuscript in preparation. , 2016.

Lei, H., Wuebbles, D. J., Liang, X. Z., Tao, Z., Olsen, S., Artz, R., Ren, X., and Cohen, M.: Projections of atmospheric mercury levels and their effect on air quality in the United States, Atmospheric Chemistry and Physics, 14, 783-795, 10.5194/acp-14-783-2014, 2014.

Lin, C.-J., Pongprueksa, P., Lindberg, S. E., Pehkonen, S. O., Byun, D., and Jang, C.: Scientific uncertainties in atmospheric mercury models I: Model science evaluation, Atmospheric Environment, 40, 2911-2928, 10.1016/j.atmosenv.2006.01.009, 2006.

Lindberg, S., Bullock, R., Ebinghaus, R., Engstrom, D., Feng, X., Fitzgerald, W., Pirrone, N., Prestbo, E., and Seigneur, C.: A synthesis of progress and uncertainties in attributing the sources of mercury in deposition, Ambio, 36, 19-32, 2007.

Lindqvist, O., and Rodhe, H.: ATMOSPHERIC MERCURY - A REVIEW, Tellus Series B-Chemical and Physical Meteorology, 37, 136-159, 1985.

Liu, H. Y., Jacob, D. J., Bey, I., and Yantosca, R. M.: Constraints from Pb-210 and Be-7 on wet deposition and transport in a global three-dimensional chemical tracer model driven by assimilated meteorological fields, Journal of Geophysical Research-Atmospheres, 106, 12109-12128, 10.1029/2000jd900839, 2001.

Mason, R.: Mercury emissions from natural processes and their importance in the global mercury cycle, Mercury Fate and Transport in the Global Atmosphere, edited by: Mason, R., Pirrone, N., Springer US, NewYork, NY, USA, 173-191 pp., 2009.

Mason, R. P., and Sheu, G. R.: Role of the ocean in the global mercury cycle, Global Biogeochemical Cycles, 16, 10.1029/2001gb001440, 2002.

Megaritis, A. G., Murphy, B. N., Racherla, P. N., Adams, P. J., and Pandis, S. N.: Impact of climate change on mercury concentrations and deposition in the eastern United States, Science of the Total Environment, 487, 299-312, 10.1016/j.scitotenv.2014.03.084, 2014.

Mergler, D., Anderson, H. A., Chan, L. H. M., Mahaffey, K. R., Murray, M., Sakamoto, M., and Stern, A. H.: Methylmercury exposure and health effects in humans: A worldwide concern, Ambio, 36, 3-11, 2007. 
MNP: Integrated modelling of global environmental change, an overview of IMAGE 2.4., edited by: Bouwman, A. F., Kram,T., and Klein Goldewijk, K., Netherlands Environmental Assessment Agency (MNP), Bilthoven, The Netherlands, 2006.

NADP: National Atmospheric Deposition Program: Mercury Deposition Network (MDN): A NADP Network, available at: http://nadp.sws.uiuc.edu/MDN/, 2009.

Nair, U. S., Wu, Y., Holmes, C. D., Ter Schure, A., Kallos, G., and Walters, J. T.: Cloud-resolving simulations of mercury scavenging and deposition in thunderstorms, Atmospheric Chemistry and Physics, 13, 10143 10157, 10.5194/acp-13-10143-2013, 2013.

Nakicenovic, N., Alcamo, J., Davis, G., de Vries, B., Fenhann, J., Gaffin, S., Gregory, K., Grbler, A., Jung, T., and Kram, T.: Special report on emission scenarios: A special report of working group III of the intergovernmental panel on climate change. In Special Report on Emissions Scenarios, Academic Publishing, New York, NY, USA, 2000.

Nightingale, P. D., Malin, G., Law, C. S., Watson, A. J., Liss, P. S., Liddicoat, M. I., Boutin, J., and UpstillGoddard, R. C.: In situ evaluation of air-sea gas exchange parameterizations using novel conservative and volatile tracers, Global Biogeochemical Cycles, 14, 373-387, 10.1029/1999gb900091, 2000.

Obrist, D., Conen, F., Vogt, R., Siegwolf, R., and Alewell, C.: Estimation of Hg-0 exchange between ecosystems and the atmosphere using $\mathrm{Rn}-222$ and $\mathrm{Hg}-0$ concentration changes in the stable nocturnal boundary layer, Atmospheric Environment, 40, 856-866, 10.1016/j.atmosenv.2005.10.012, 2006.

Pacyna, E. G., Pacyna, J. M., Sundseth, K., Munthe, J., Kindbom, K., Wilson, S., Steenhuisen, F., and Maxson, P.: Global emission of mercury to the atmosphere from anthropogenic sources in 2005 and projections to 2020, Atmospheric Environment, 44, 2487-2499, 10.1016/j.atmosenv.2009.06.009, 2010.

Parrella, J. P., Jacob, D. J., Liang, Q., Zhang, Y., Mickley, L. J., Miller, B., Evans, M. J., Yang, X., Pyle, J. A., Theys, N., and Van Roozendael, M.: Tropospheric bromine chemistry: implications for present and preindustrial ozone and mercury, Atmospheric Chemistry and Physics, 12, 6723-6740, 10.5194/acp-126723-2012, 2012.

Pirrone, N., Cinnirella, S., Feng, X., Finkelman, R. B., Friedli, H. R., Leaner, J., Mason, R., Mukherjee, A. B., Stracher, G. B., Streets, D. G., and Telmer, K.: Global mercury emissions to the atmosphere from anthropogenic and natural sources, Atmospheric Chemistry and Physics, 10, 5951-5964, 10.5194/acp10-5951-2010, 2010.

Poissant, L., Pilote, M., and Casimir, A.: Mercury flux measurements in a naturally enriched area: Correlation with environmental conditions during the Nevada Study and Tests of the Release of Mercury From Soils (STORMS), Journal of Geophysical Research-Atmospheres, 104, 21845-21857, 10.1029/1999jd900092, 1999.

Poissant, L., Amyot, M., Pilote, M., and Lean, D.: Mercury water-air exchange over the Upper St. Lawrence River and Lake Ontario, Environmental Science \& Technology, 34, 3069-3078, 10.1021/es990719a, 2000.

Pongprueksa, P., Lin, C.-J., Lindberg, S. E., Jang, C., Braverman, T., Bullock, O. R., Jr., Ho, T. C., and Chu, H.-W.: Scientific uncertainties in atmospheric mercury models III: Boundary and initial conditions, model grid resolution, and $\mathrm{Hg}(\mathrm{II})$ reduction mechanism, Atmospheric Environment, 42, 1828-1845, 10.1016/j.atmosenv.2007.11.020, 2008. 
Prestbo, E. M., and Gay, D. A.: Wet deposition of mercury in the US and Canada, 1996-2005: Results and analysis of the NADP mercury deposition network (MDN), Atmospheric Environment, 43, 4223-4233, 10.1016/j.atmosenv.2009.05.028, 2009.

Rind, D., Lerner, J., Jonas, J., and McLinden, C.: Effects of resolution and model physics on tracer transports in the NASA Goddard Institute for Space Studies general circulation models, Journal of Geophysical Research-Atmospheres, 112, 10.1029/2006jd007476, 2007.

Risch, M. R., DeWild, J. F., Krabbenhoft, D. P., Kolka, R. K., and Zhang, L.: Litterfall mercury dry deposition in the eastern USA, Environmental Pollution, 161, 284-290, 10.1016/j.envpol.2011.06.005, 2012a.

Risch, M. R., Gay, D. A., Fowler, K. K., Keeler, G. J., Backus, S. M., Blanchard, P., Barres, J. A., and Dvonch, J. T.: Spatial patterns and temporal trends in mercury concentrations, precipitation depths, and mercury wet deposition in the North American Great Lakes region, 2002-2008, Environmental Pollution, 161, 261-271, 10.1016/j.envpol.2011.05.030, 2012b.

Rutter, A. P., and Schauer, J. J.: The effect of temperature on the gas-particle partitioning of reactive mercury in atmospheric aerosols, Atmospheric Environment, 41, 8647-8657, 10.1016/j.atmosenv.2007.07.024, 2007a.

Rutter, A. P., and Schauer, J. J.: The impact of aerosol composition on the particle to gas partitioning of reactive mercury, Environmental Science \& Technology, 41, 3934-3939, 10.1021/es062439i, 2007b.

Rutter, A. P., Schauer, J. J., Shafer, M. M., Creswell, J. E., Olson, M. R., Robinson, M., Collins, R. M., Parman, A. M., Katzman, T. L., and Mallek, J. L.: Dry deposition of gaseous elemental mercury to plants and soils using mercury stable isotopes in a controlled environment, Atmospheric Environment, 45, 848855, 10.1016/j.atmosenv.2010.11.025, 2011.

Scheulhammer, A. M., Meyer, M. W., Sandheinrich, M. B., and Murray, M. W.: Effects of environmental methylmercury on the health of wild birds, mammals, and fish, Ambio, 36, 12-18, 10.1579/00447447(2007)36[12:eoemot]2.0.co;2, 2007.

Schroeder, W. H., and Munthe, J.: Atmospheric mercury - An overview, Atmospheric Environment, 32, 809-822, 10.1016/s1352-2310(97)00293-8, 1998.

Seigneur, C., Vijayaraghavan, K., Lohman, K., Karamchandani, P., and Scott, C.: Global source attribution for mercury deposition in the United States, Environmental Science \& Technology, 38, 555-569, 10.1021/es034109t, 2004.

Selin, N. E., Jacob, D. J., Park, R. J., Yantosca, R. M., Strode, S., Jaegle, L., and Jaffe, D.: Chemical cycling and deposition of atmospheric mercury: Global constraints from observations, Journal of Geophysical Research-Atmospheres, 112, 10.1029/2006jd007450, 2007.

Selin, N. E., and Jacob, D. J.: Seasonal and spatial patterns of mercury wet deposition in the United States: Constraints on the contribution from North American anthropogenic sources, Atmospheric Environment, 42, 5193-5204, 10.1016/j.atmosenv.2008.02.069, 2008.

Selin, N. E., Jacob, D. J., Yantosca, R. M., Strode, S., Jaegle, L., and Sunderland, E. M.: Global 3-D landocean-atmosphere model for mercury: Present-day versus preindustrial cycles and anthropogenic enrichment factors for deposition (vol 22, artn no GB3099, 2008), Global Biogeochemical Cycles, 22, 10.1029/2008gb003282, 2008.

Selin, N. E.: Global Biogeochemical Cycling of Mercury: A Review, Annual Review of Environment and Resources, 34, 43-63, 10.1146/annurev.environ.051308.084314, 2009. 
Selin, N. E.: GLOBAL CHANGE AND MERCURY CYCLING: CHALLENGES FOR IMPLEMENTING A GLOBAL MERCURY TREATY, Environmental Toxicology and Chemistry, 33, 1202-1210, 10.1002/etc.2374, 2014.

Shia, R. L., Seigneur, C., Pai, P., Ko, M., and Sze, N. D.: Global simulation of atmospheric mercury concentrations and deposition fluxes, Journal of Geophysical Research-Atmospheres, 104, 23747-23760, 10.1029/1999jd900354, 1999.

Sitch, S., Smith, B., Prentice, I. C., Arneth, A., Bondeau, A., Cramer, W., Kaplan, J. O., Levis, S., Lucht, W., Sykes, M. T., Thonicke, K., and Venevsky, S.: Evaluation of ecosystem dynamics, plant geography and terrestrial carbon cycling in the LPJ dynamic global vegetation model, Glob. Change Biol., 9, 161-185, 10.1046/j.1365-2486.2003.00569.x, 2003.

Soerensen, A. L., Sunderland, E. M., Holmes, C. D., Jacob, D. J., Yantosca, R. M., Skov, H., Christensen, J. H., Strode, S. A., and Mason, R. P.: An Improved Global Model for Air-Sea Exchange of Mercury: High Concentrations over the North Atlantic, Environmental Science \& Technology, 44, 8574-8580, 10.1021/es102032g, 2010.

Soerensen, A. L., Mason, R. P., Balcom, P. H., and Sunderland, E. M.: Drivers of Surface Ocean Mercury Concentrations and Air-Sea Exchange in the West Atlantic Ocean, Environmental Science \& Technology, 47, 7757-7765, 10.1021/es401354q, 2013.

Soerensen, A. L., Mason, R. P., Balcom, P. H., Jacob, D. J., Zhang, Y., Kuss, J., and Sunderland, E. M.: Elemental Mercury Concentrations and Fluxes in the Tropical Atmosphere and Ocean, Environmental Science \& Technology, 48, 11312-11319, 10.1021/es503109p, 2014.

Soerensen, A. L., Jacob, D. J., Schartup, A. T., Fisher, J. A., Lehnherr, I., Louis, V. L. S., Heimbürger, L.-E., J. E. Sonke, Krabbenhoft, D. P., and Sunderland, E. M.: A mass budget for mercury and methylmercury in the Arctic Ocean, Global Biogeochemical Cycles, 30, 560-575, 10.1002/2015GB005280, 2016.

Song, S., Selin, N. E., Soerensen, A. L., Angot, H., Artz, R., Brooks, S., Brunke, E. G., Conley, G., Dommergue, A., Ebinghaus, R., Holsen, T. M., Jaffe, D. A., Kang, S., Kelley, P., Luke, W. T., Magand, O., Marumoto, K., Pfaffhuber, K. A., Ren, X., Sheu, G. R., Slemr, F., Warneke, T., Weigelt, A., Weiss-Penzias, P., Wip, D. C., and Zhang, Q.: Top-down constraints on atmospheric mercury emissions and implications for global biogeochemical cycling, Atmospheric Chemistry and Physics, 15, 7103-7125, 10.5194/acp-157103-2015, 2015.

Stern, G. A., Macdonald, R. W., Outridge, P. M., Wilson, S., Chetelat, J., Cole, A., Hintelmann, H., Loseto, L. L., Steffen, A., Wang, F., and Zdanowicz, C.: How does climate change influence arctic mercury?, Science of the Total Environment, 414, 22-42, 10.1016/j.scitotenv.2011.10.039, 2012.

Streets, D. G., Zhang, Q., and Wu, Y.: Projections of Global Mercury Emissions in 2050, Environmental Science \& Technology, 43, 2983-2988, 10.1021/es802474j, 2009.

Strode, S. A., Jaegle, L., Selin, N. E., Jacob, D. J., Park, R. J., Yantosca, R. M., Mason, R. P., and Slemr, F.: Air-sea exchange in the global mercury cycle, Global Biogeochemical Cycles, 21, 10.1029/2006gb002766, 2007.

Subir, M., Ariya, P. A., and Dastoor, A. P.: A review of uncertainties in atmospheric modeling of mercury chemistry I. Uncertainties in existing kinetic parameters - Fundamental limitations and the importance of heterogeneous chemistry, Atmospheric Environment, 45, 5664-5676, 10.1016/j.atmosenv.2011.04.046, 2011. 
Subir, M., Ariya, P. A., and Dastoor, A. P.: A review of the sources of uncertainties in atmospheric mercury modeling II. Mercury surface and heterogeneous chemistry - A missing link, Atmospheric Environment, 46, 1-10, 10.1016/j.atmosenv.2011.07.047, 2012.

Sunderland, E. M., and Mason, R. P.: Human impacts on open ocean mercury concentrations, Global Biogeochemical Cycles, 21, 10.1029/2006gb002876, 2007.

Turner, B. L., Meyer, W. B., and Skole, D. L.: GLOBAL LAND-USE LAND-COVER CHANGE - TOWARDS AN INTEGRATED STUDY, Ambio, 23, 91-95, 1994.

UNEP: Global Mercury Assessment 2013: Sources, Emissions, Releases and Environmental Transport, UNEP Chemicals Branch, Geneva, Switzerland, 2013.

van der Werf, G. R., Randerson, J. T., Giglio, L., Collatz, G. J., Mu, M., Kasibhatla, P. S., Morton, D. C., DeFries, R. S., Jin, Y., and van Leeuwen, T. T.: Global fire emissions and the contribution of deforestation, savanna, forest, agricultural, and peat fires (1997-2009), Atmospheric Chemistry and Physics, 10, 1170711735, 10.5194/acp-10-11707-2010, 2010.

Wang, Q., Jacob, D. J., Fisher, J. A., Mao, J., Leibensperger, E. M., Carouge, C. C., Le Sager, P., Kondo, Y., Jimenez, J. L., Cubison, M. J., and Doherty, S. J.: Sources of carbonaceous aerosols and deposited black carbon in the Arctic in winter-spring: implications for radiative forcing, Atmospheric Chemistry and Physics, 11, 12453-12473, 10.5194/acp-11-12453-2011, 2011.

Wang, X., Lin, C. J., and Feng, X.: Sensitivity analysis of an updated bidirectional air-surface exchange model for elemental mercury vapor, Atmospheric Chemistry and Physics, 14, 6273-6287, 10.5194/acp14-6273-2014, 2014.

Wang, Y., Jacob, D. J., J., L. D., and A., L. J.: Global simulation of tropospehric O3-NOx-hydrocarbon chmistry. 1. Model formulation, Journal of Geophysical Research, 103, 10713-10725, 1998.

Wesely, M. L.: PARAMETERIZATION OF SURFACE RESISTANCES TO GASEOUS DRY DEPOSITION IN REGIONAL-SCALE NUMERICAL-MODELS, Atmospheric Environment, 23, 1293-1304, 10.1016/00046981(89)90153-4, 1989.

Wilks, D. S.: Hypothesis Testing, in: Statistical Methods in the Atmospheric Sciences, Second ed., Academic Press, 138-146, 2006.

Wu, S., Mickley, L. J., Jacob, D. J., Logan, J. A., Yantosca, R. M., and Rind, D.: Why are there large differences between models in global budgets of tropospheric ozone?, Journal of Geophysical ResearchAtmospheres, 112, 10.1029/2006jd007801, 2007.

Wu, S., Mickley, L. J., Kaplan, J. O., and Jacob, D. J.: Impacts of changes in land use and land cover on atmospheric chemistry and air quality over the 21st century, Atmospheric Chemistry and Physics, 12, 1597-1609, 10.5194/acp-12-1597-2012, 2012.

Xu, X. H., Yang, X. S., Miller, D. R., Helble, J. J., and Carley, R. J.: Formulation of bi-directional atmosphere-surface exchanges of elemental mercury, Atmospheric Environment, 33, 4345-4355, 10.1016/s1352-2310(99)00245-9, 1999.

Zhang, H., Lindberg, S. E., Marsik, F. J., and Keeler, G. J.: Mercury air/surface exchange kinetics of background soils of the Tahquamenon River watershed in the Michigan Upper Peninsula, Water Air and Soil Pollution, 126, 151-169, 10.1023/a:1005227802306, 2001. 
Zhang, L., Wright, L. P., and Blanchard, P.: A review of current knowledge concerning dry deposition of atmospheric mercury, Atmospheric Environment, 43, 5853-5864, 10.1016/j.atmosenv.2009.08.019, 2009.

Zhang, L., Blanchard, P., Gay, D. A., Prestbo, E. M., Risch, M. R., Johnson, D., Narayan, J., Zsolway, R., Holsen, T. M., Miller, E. K., Castro, M. S., Graydon, J. A., St Louis, V. L., and Dalziel, J.: Estimation of speciated and total mercury dry deposition at monitoring locations in eastern and central North America, Atmospheric Chemistry and Physics, 12, 4327-4340, 10.5194/acp-12-4327-2012, 2012a.

Zhang, Y., Jaegle, L., van Donkelaar, A., Martin, R. V., Holmes, C. D., Amos, H. M., Wang, Q., Talbot, R., Artz, R., Brooks, S., Luke, W., Holsen, T. M., Felton, D., Miller, E. K., Perry, K. D., Schmeltz, D., Steffen, A., Tordon, R., Weiss-Penzias, P., and Zsolway, R.: Nested-grid simulation of mercury over North America, Atmospheric Chemistry and Physics, 12, 6095-6111, 10.5194/acp-12-6095-2012, 2012b.

Zhang, Y., and Jaegle, L.: Decreases in Mercury Wet Deposition over the United States during 2004-2010: Roles of Domestic and Global Background Emission Reductions, Atmosphere, 4, 113-131, 10.3390/atmos4020113, 2013.

Zhang, Y., Jaegle, L., and Thompson, L.: Natural biogeochemical cycle of mercury in a global threedimensional ocean tracer model, Global Biogeochemical Cycles, 28, 553-570, 10.1002/2014gb004814, 2014a.

Zhang, Y., Jaegle, L., Thompson, L., and Streets, D. G.: Six centuries of changing oceanic mercury, Global Biogeochemical Cycles, 28, 1251-1261, 10.1002/2014gb004939, 2014b.

Zhang, Y., Jacob, D. J., Dutkiewicz, S., Amos, H. M., Long, M. S., and Sunderland, E. M.: Biogeochemical drivers of the fate of riverine mercury discharged to the global and Arctic oceans, Global Biogeochemical Cycles, 29, 854-864, 10.1002/2015gb005124, 2015.

Zhu, W., Lin, C.-J., Wang, X., Sommar, J., Fu, X., and Feng, X.: Global observations and modeling of atmosphere-surface exchange of elemental mercury: a critical review, Atmospheric Chemistry and Physics, 16, 4451-4480, 10.5194/acp-16-4451-2016, 2016. 